\title{
Article \\ Developing Community Disaster Resilience in the Lembang Fault Area, Indonesia: Lessons Learned from Japanese Experience
}

\author{
Rizqi Abdulharis ${ }^{1, *(D)}$, Alfita Puspa Handayani ${ }^{1}$, Chikako Isouchi ${ }^{2}$ and Irwan Meilano ${ }^{1}$ \\ 1 Department of Geodesy and Geomatics Engineering, Surveying and Cadastre Research Division, \\ Institut Teknologi Bandung, Kota Bandung 40132, Jawa Barat, Indonesia; alfitapuspa@gd.itb.ac.id (A.P.H.); \\ irwanm@itb.ac.id (I.M.) \\ 2 Institute of Education, Research and Regional Cooperation for Crisis Management Shikoku, \\ Kagawa University, Kagawa 760-0016, Japan; isouchi.chikako@kagawa-u.ac.jp \\ * Correspondence: rabdulharis@gd.itb.ac.id; Tel.: +62-22-2530701
}

check for updates

Citation: Abdulharis, R.; Handayani, A.P.; Isouchi, C.; Meilano, I. Developing Community Disaster Resilience in the Lembang Fault Area, Indonesia: Lessons Learned from Japanese Experience. Appl. Sci. 2022, 12, 1271. https://doi.org/10.3390/ app12031271

Academic Editor: Jason K. Levy

Received: 16 November 2021

Accepted: 6 January 2022

Published: 25 January 2022

Publisher's Note: MDPI stays neutral with regard to jurisdictional claims in published maps and institutional affiliations.

Copyright: (c) 2022 by the authors Licensee MDPI, Basel, Switzerland. This article is an open access article distributed under the terms and conditions of the Creative Commons Attribution (CC BY) license (https:// creativecommons.org/licenses/by/ $4.0 /)$.
Featured Application: The outputs of the research that is highlighted in this paper are based on the assessment of community disaster resilience in a geological hazard-prone area, which is characterized by a social, economic, and environmental system of people and area of the central part of Western Java province, Indonesia. While the concept and benchmark of CDR development that were utilized in this research were developed based on various types of disasters, there are common domains, subcategories, and sub-subcategories that may be employed to develop CDR in various circumstances. Thus, the conceptual framework of the research may be implemented elsewhere by considering social, economic, and environmental characteristics of the area in question. It may require adjustments for the application of the conceptual framework beyond the case study area of the research.

Abstract: Having experienced large-scale disasters between 2004 and 2006, the fatalities due to large-scale disasters in 2018 in Indonesia were still high. In contrast, community disaster resilience (CDR) and disaster risk management (DRM) in Japan have been continuously improved. Thus, there is a need to develop CDR for supporting DRM in Indonesia by learning from the Japanese experience, particularly in a disaster-prone area without large-scale disaster experience. This research was a pilot project on the development of CDR in Indonesia. The case study was Lembang Fault area, which is a geologic hazard-prone area. People's perception was collected using structured interviews, while demographic and local economic data were acquired from official statistical publications. Satellite images were utilized to acquire the imageries of natural and built environment, as well as land use/land cover and its changes, between 2019 and 2021. Based on CDR assessment in the Lembang Fault area, the levels of people's participation and capacity on DRM were low. This may be caused by the low level of training and education, linking of social capital and past disaster experience, as well as the inability of the people to interpret the symbols in indigenous knowledge. Moreover, government interventions on DRM and land administration are required to develop CDR in the Lembang Fault area. Organized community development is expected rather than to solely involve universities and NGOs. Furthermore, strategies to develop economic resilience are needed to allow the community to bounce back from future disaster. Finally, baseline data should be collected and managed to develop DRM strategy and CDR.

Keywords: community disaster resilience; disaster risk management; Lembang Fault; Indonesia; Japan

\section{Introduction}

Community disaster resilience (CDR) has been defined differently based on various points of view of researchers, namely an ongoing process of adaptation, the absence of negative effects, the presence of a range of positive attributes, or a mixture of the 
mentioned types of definition [1]. The first type of definition mainly refers to a process of the attainment of positive outcomes at individual, family, and community levels despite adversity [1,2] using shared and unique capacities to manage and adaptively respond to the extraordinary demands on resources and the losses associated with disaster [1,3-5] to be able to have a positive trajectory of functioning and adaptation in constituent populations after a disturbance $[1,4]$.

The second type of definition deals with the expected outcome of keeping functioning [1]. This includes psychological and physical functioning for the individual level $[1,4,6]$, as well as evidence on the capability of an organization to contend with uncertainty [1,7].

The third type of definition describes positive attributes of a CDR [1]. Those attributes are responsiveness and the existence of collective action of local support [1,8]; community's capacities, skills, and knowledge [1,4]; and household relationships, the level of education and literacy, employment-seeking behaviors, social support networks, the ability to seek support services, a sense of communal safety and hope, and physical security measures $[1,9]$.

Despite the nonexistence of a common definition on CDR, there are common elements that are best to represent CDR, which affects the way to measure it [1]. Most importantly, enhancement of the community to be a resilient one through a paradigm shift and a new culture of disaster resilience is what matters most [10].

Nonetheless, community disaster resilience (CDR) is pivotal to disaster risk management (DRM). DRM is described as a systematic process of using administrative directives, organizations, and operational skills and capacities to implement strategies, policies, and improved coping capacities in order to lessen the adverse impact of hazards and the possibility of disaster [11]. Although DRM covers activities on prevention, mitigation, preparedness, response, and recovery from disaster, it is dominated by response and recovery activities [12]. On the other hand, CDR focuses on mitigation and preparedness activities, as well as recovery processes [13]. Moreover, CDR emphasizes the need to reduce impacts of disaster [12,14]. Thus, CDR becomes an important part of DRM.

The degrees of DRM and CDR in Indonesia are arguably low. Having experienced large-scale disasters caused by earthquakes and tsunamis between 2004 and 2006, the number of fatalities caused by other large-scale disasters in 2018 in Indonesia were still high. Such facts have created uneasiness to the people of Indonesia as the number of natural hazards had been increasing between 2015 and 2020. See Figure 1 for details.

On the other hand, DRM and CDR development in Japan have been continuously improved. Due to the lessons learned from Typhoon Ise Bay in 1959, the Japanese government enacted the Disaster Countermeasure Basic Act. The act was revised in 2011 as the Great East Japan Earthquake still caused more than 20,000 casualties. In recent years, non-structural measures on DRM, such as disaster education and planning, have become more important. This is primarily because public sector was also damaged due to the 2011 Great East Japan Earthquake. DRM has been incorporated into elementary school curriculum across the board. Such measures include participation of the private and community sector. In addition, there are some examples of joint disaster prevention mapping and disaster drills with residents. Above all, structural measures that include the construction of protective facilities are still being performed. 


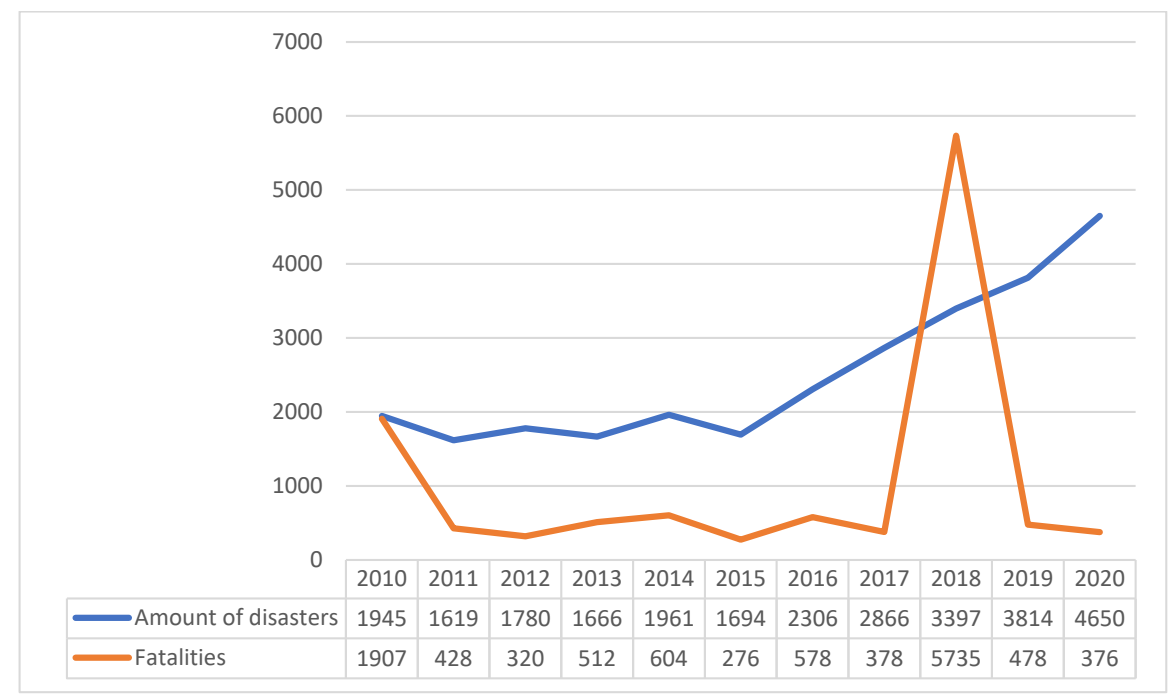

Figure 1. The number of natural hazards, including flood, tornado, landslide, earthquake, forest and land fire, tidal and abrasion and volcanic eruption, as well as their fatalities in Indonesia between 2010 and 2020 [15-25].

CDR has also been studied in Indonesia. Based on the experiences of various stakeholders who recently experienced large-scale disaster events in Indonesia, there are five CDR domains, namely social, economic, institutional, infrastructural, and environmental domains [26]. Such domains were implemented to quantitatively assess CDR on flood disaster in a district, or kecamatan in Bahasa Indonesia, in the municipality of Bojonegoro of the Eastern Java province [27]. Another research focused on the assessment of social domain of CDR in post-disaster area [28].

Unfortunately, there is a lack of information on CDR development in disaster-prone area. Moreover, there is no explanation yet on the difficulties to relocate people to a safer area, such as in the municipality of Banda Aceh of the Aceh province after the 2004 Indian Ocean Tsunami [29], as well as in the municipality of Pandeglang of the Banten province after the 2018 Sunda Strait Tsunami and in the municipality of Sukabumi of the Western Java province after the 2018 landslide [28].

One of the objectives of the research highlighted in this paper was to develop community resilience to disaster in Indonesia. The research considered the Japanese experience on developing CDR in Indonesia. This research also put in mind special social, economic, institutional, infrastructural, and environmental characteristics of Indonesia. Most importantly, the research focused on the development of CDR in a disaster-prone area to explore the possibility to develop a resilient community that has not experienced a large-scale disaster. It is expected that the community will be adequately resilient in case of the occurrence of various scale of disaster.

Furthermore, the mentioned research was not intended to assess the degree of community resilience in Indonesia. Rather, the research focussed on closing the gaps on CDR development on each subcategory. Furthermore, this paper highlights the completeness of data concerning the existing CDR condition.

To initiate the development of CDR in a disaster-prone area without any experience on a large-scale disaster occurrence, the Lembang Fault area was chosen as the pilot. Extending approximately $29 \mathrm{~km}$ in the west-east direction to the north of the muncipality of city of Bandung, the Lembang Fault area is a geological hazard-prone area. Between 2010 and 2017, 13 earthquakes with magnitude between 0.4 and 3.3 Mw occurred in the area [30]. With the annual fault movement of $6 \mathrm{~mm}$ [31], Lembang Fault activity may produce an earthquake with a magnitude between 6.5 and $7.0 \mathrm{Mw}$, and a repetition time between 170 and 670 years [32]. Development of CDR in the Lembang Fault area is considerably important as the hazard may affect 8 million people in the municipality of the city of 
Bandung, the municipality of Western Bandung, the municipality of Bandung, and the municipality of the city of Cimahi [33].

\section{Materials and Methods}

The research employed a case study approach. The focus of the highlighted study was the central part of the Lembang Fault, which is located in the municipality of Western Bandung and the municipality of the city of Bandung. The analysis of CDR unit was the central part of the Lembang Fault area, which comprises of four districts in the districts of Parongpong, Cisarua, and Lembang of the municipality of Western Bandung, as well as the district of Sukasari of the municipality of the city of Bandung.

To provide an overview of demographic and local economic characteristics of the case study area, the publications of the Statistics of Indonesia, or Badan Pusat Statistik (BPS) in Bahasa Indonesia, on the social and economic statistics of the four districts were utilized. For acquiring information concerning natural and built environment and land use/land cover, as well as their changes between 2019 and 2021, Level 2A Sentinel-2 satellite images, geometrically corrected by means of bottom-of-atmosphere (BOA) radiometric correction of reflectance, were employed. The satellite images were processed by means of a supervised classification method. See Figures 2-4 for details. Information concerning policy, regulations, and procedures on DRM were acquired from regulations at national, provincial, and local levels. Furthermore, two types of interviews were performed. First, to acquire information on risk knowledge particularly indigenous knowledge on risks, as well as CDR and DRM in general in the Lembang Fault area, a semi-structured interview was performed. Second, to obtain a deeper understanding concerning people's perception in the scope of other subcategories of CDR, face-to-face structured interviews were conducted with 108 heads of families living in 16 villages within four districts of the Lembang Fault area. The respondents directly provided their answers during the interviews. Additionally, the respondents were allowed to provide more than one answer for each question, while several respondents did not provide answers for few sensitive questions. All interviews were conducted between 31 May and 11 June 2021. See Figure 5 for the location of survey of this research. See also Table 1 for the characteristics of the respondents. The highlighted research also collected information on the Japanese experience on the development of CDR, whose information is a result of a long-term research on CDR.

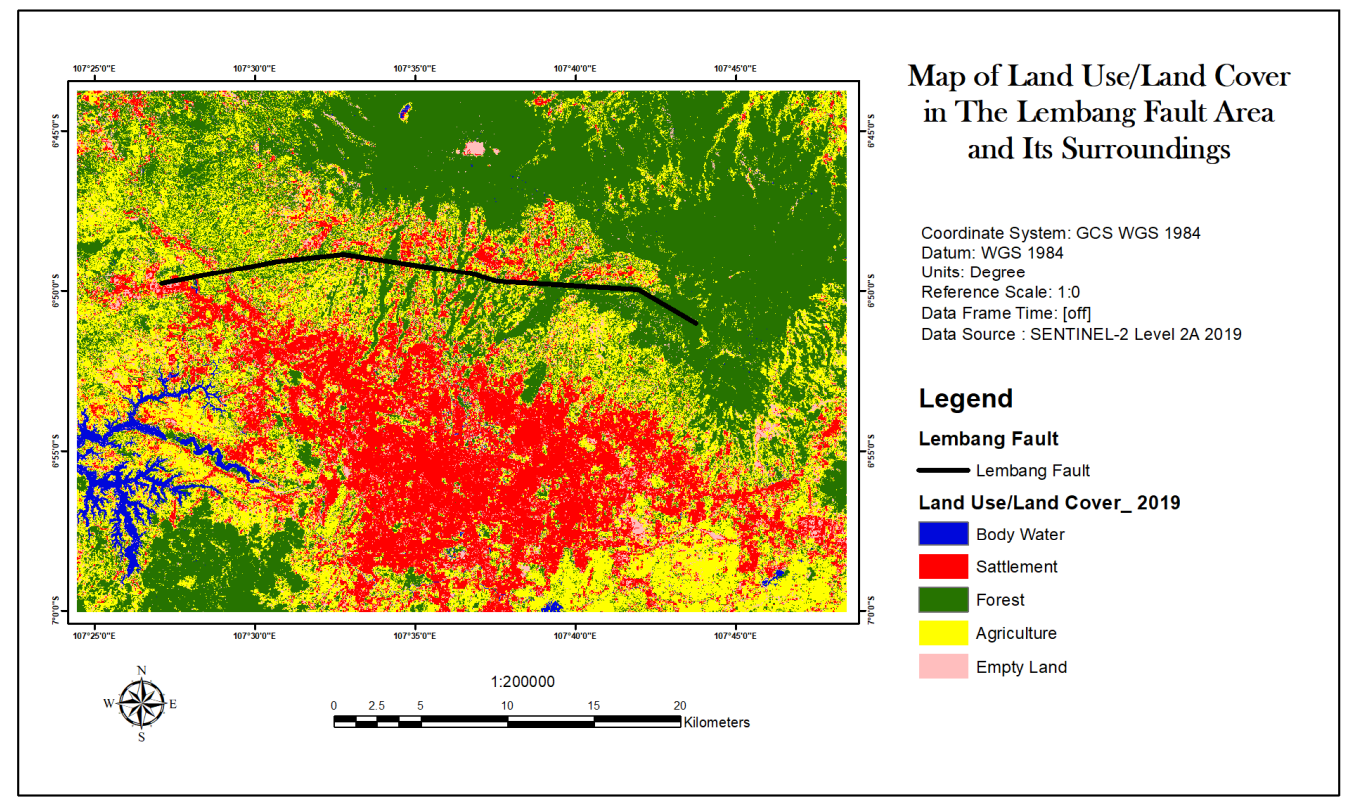

Figure 2. Land use/land cover of Lembang Fault in 2019. In 2019, the land use/land cover of the Lembang Fault area was dominated by forest (44.55\%) and agricultural land (30.60\%). Settlement areas coverage was $22.80 \%$. 


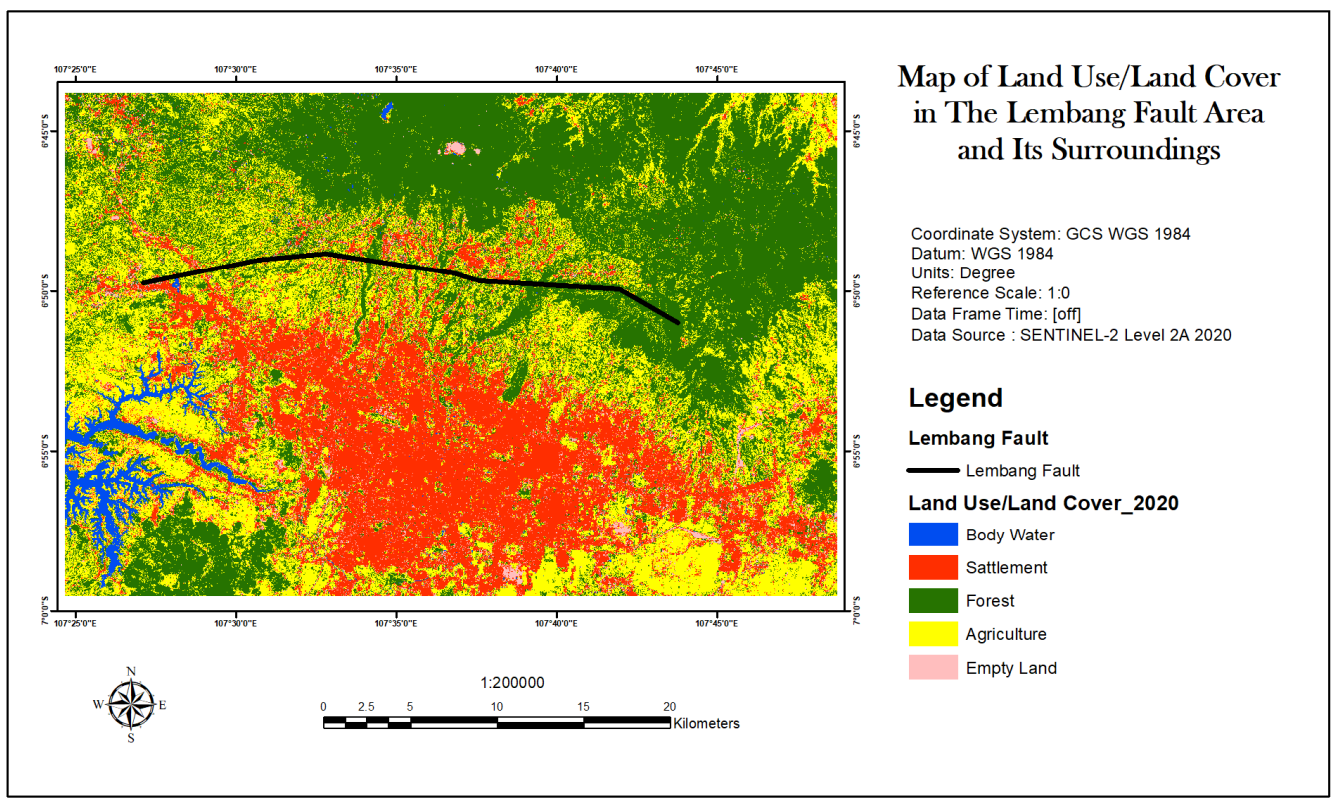

Figure 3. Land use/land cover of Lembang Fault in 2020. Between 2019 and 2020, the coverage of forest had decreased 17,758 ha, while the coverage of settlement areas and agricultural land had increased as much as 18,647 ha and 10,670 ha, respectively.

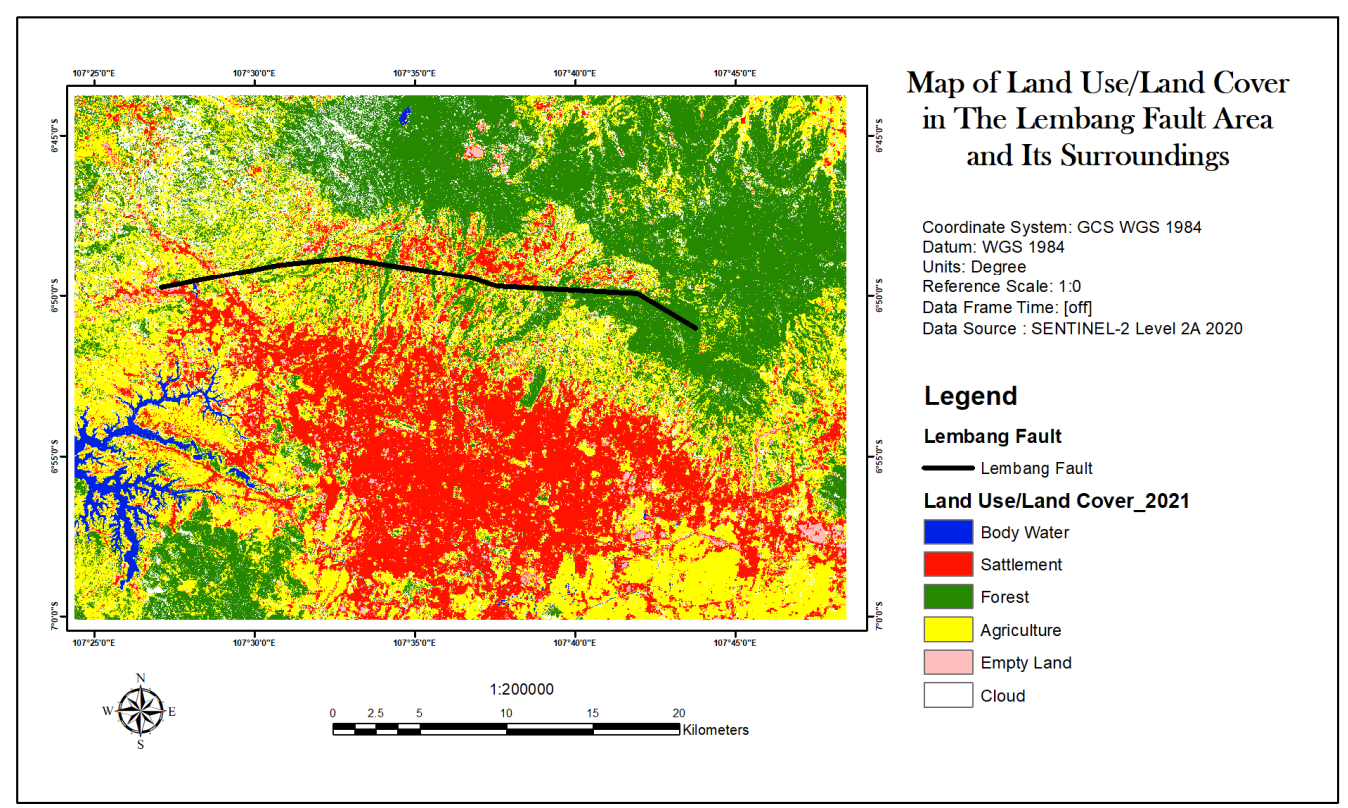

Figure 4. Land use/land cover of the Lembang Fault area in 2021. The coverage of forest between 2020 and 2021 had drastically decreased 116,605 ha, while agricultural land coverage at the same period had increased 35,858 ha. In 2021, the coverage of agricultural land (421,646 ha) was already higher than it of forest $(411,644 \mathrm{ha})$. 


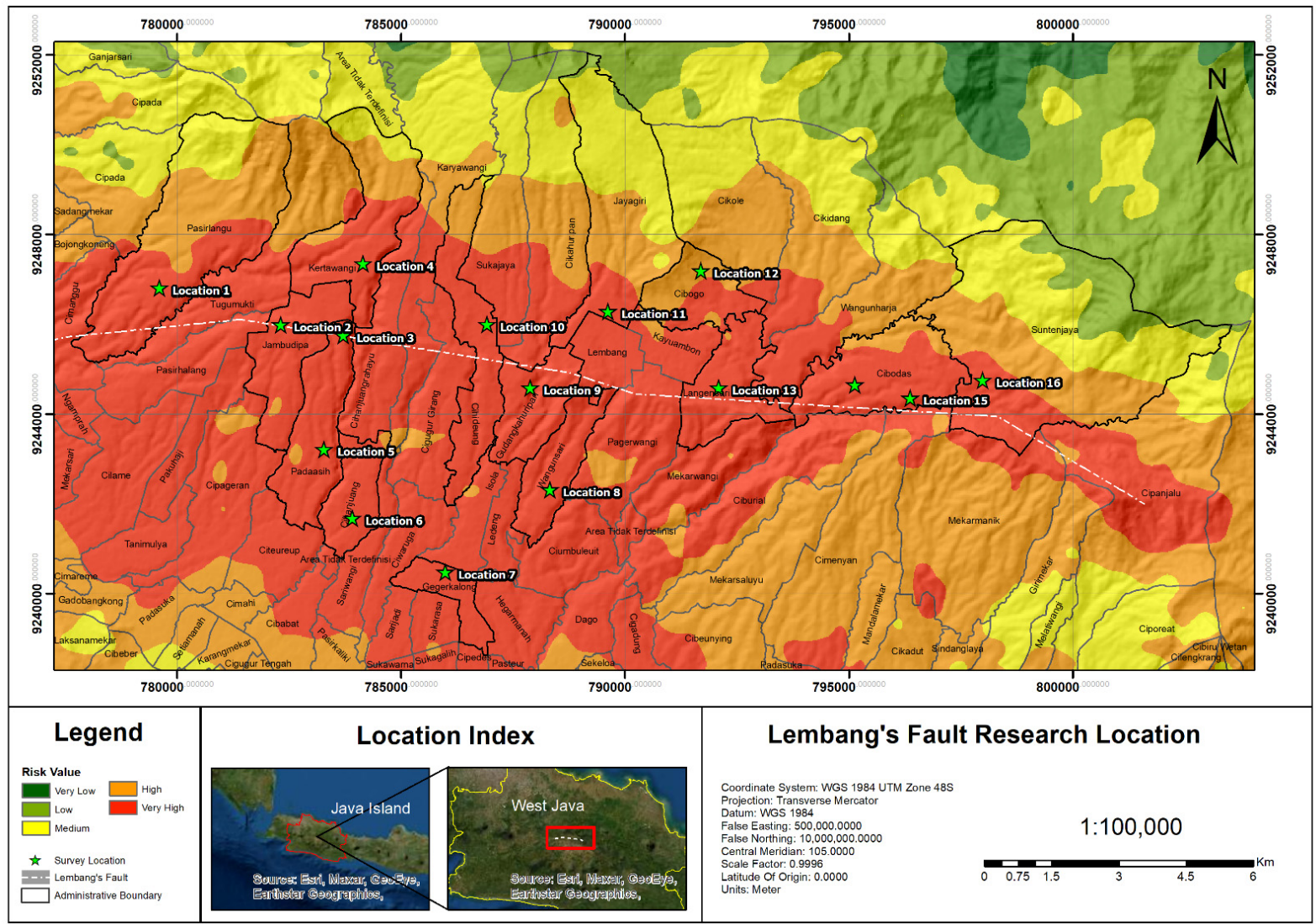

Figure 5. Location of survey in the Lembang Fault area.

Table 1. Characteristics of the respondents.

\begin{tabular}{|c|c|c|c|c|c|}
\hline & $\begin{array}{c}\text { District of } \\
\text { Parongpong }\end{array}$ & District of Cisarua & District of Lembang & District of Sukasari & Overall \\
\hline $\begin{array}{l}\text { No. of } \\
\text { respondent }\end{array}$ & $11(10.19 \%)$ & $37(34.26 \%)$ & $54(50.00 \%)$ & $6(5.56 \%)$ & $108(100 \%)$ \\
\hline Age & $\begin{array}{l}\text { Age (A) 20-35: 0, A } \\
\text { 35-60: } 11(100 \%), A \\
\text { over 60: } 0, \text { A not } \\
\text { specified: } 0\end{array}$ & $\begin{array}{l}\text { A 20-35: } 4(10.81 \%), \\
\text { A 35-60: } 29(78.38 \%), \\
\text { A over 60: } 2 \text { (5.41\%), } \\
\text { A not specified: } 2 \\
(5.41 \%)\end{array}$ & $\begin{array}{l}\text { A 20-35: } 10(18.52 \%), \text { A } \\
\text { 35-60: } 34(62.96 \%), A \\
\text { over 60: } 8(14.81 \%), A \text { not } \\
\text { specified: } 2(3.79 \%)\end{array}$ & $\begin{array}{l}\text { A 20-35: 0, A 35-60: } \\
5(83.33 \%), \text { A over } 60: \\
1 \text { (16.67\%), A not } \\
\text { specified: } 0\end{array}$ & $\begin{array}{l}\text { A 20-35: } 14(12.96 \%), \text { A } \\
\text { 35-60: } 79(73.15 \%), \text { A over } \\
\text { 60: } 11(10.19 \%), \text { A not } \\
\text { specified: } 4(3.70 \%)\end{array}$ \\
\hline Sex & $\begin{array}{c}\text { Male 4 }(36.36 \%), \\
\text { female 6 }(54.55 \%), \text {,not } \\
\text { specified 1 }(9.09 \%)\end{array}$ & $\begin{array}{c}\text { Male } 10(27.03 \%) \\
\text { female } 25(67.57 \%) \\
\text { not specified } 2 \\
(5.41 \%)\end{array}$ & $\begin{array}{c}\text { Male } 19(35.19 \%) \text {, female } \\
32(59.26 \%), \text { not specified } \\
3(5.56 \%)\end{array}$ & $\begin{array}{l}\text { Male 0, female } 6 \\
\quad(100 \%) \text {, not } \\
\text { specified } 0\end{array}$ & $\begin{array}{c}\text { Male } 33(30.56 \%) \text {, female } 69 \\
(63.89 \%), \text { not specified } 6 \\
(5.56 \%)\end{array}$ \\
\hline Education & $\begin{array}{c}\text { Primary } 1(9.09 \%) \text {, } \\
\text { junior high } 7 \\
(63.64 \%) \text {, senior high } \\
3(27.27 \%) \text {, higher } \\
\text { education 0, not } \\
\text { specified 0 }\end{array}$ & $\begin{array}{c}\text { Primary } 16(43.24 \%), \\
\text { junior high } 9 \\
(24.32 \%), \text { senior high } \\
9(24.32 \%), \text { higher } \\
\text { education } 1(2.70 \%), \\
\text { not specified } 2 \\
(5.41 \%)\end{array}$ & $\begin{array}{c}\text { Primary } 20(37.04 \%), \\
\text { junior high } 15(27.78 \%), \\
\text { senior high } 14(25.93 \%), \\
\text { higher education } 4 \\
(7.41 \%), \text { not specified } 1 \\
(1.85 \%)\end{array}$ & $\begin{array}{l}\text { Primary 0, junior } \\
\text { high 0, senior high } 4 \\
(66.67 \%), \text { higher } \\
\text { education 2 (33.33), } \\
\text { not specified } 0\end{array}$ & $\begin{array}{c}\text { Primary } 37(34.26 \%) \text {, junior } \\
\text { high } 31(28.70 \%) \text {, senior } \\
\text { high } 30(27.78 \%) \text {, higher } \\
\text { education } 7(6.48 \%), \text { not } \\
\text { specified } 3(2.78 \%)\end{array}$ \\
\hline Occupation & $\begin{array}{c}\text { Trader } 2(18.18 \%), \\
\text { casual worker } 2 \\
(18.18 \%), \\
\text { entrepreneur } 5 \\
(45.45 \%), \text { Private } \\
\text { sector employee } 1 \\
(9.09 \%), \text { driver } 1 \\
(9.09 \%)\end{array}$ & $\begin{array}{c}\text { Housewife } 2(5.41 \%), \\
\text { farmer } 7(18.92 \%), \\
\text { trader } 5(13.51 \%), \\
\text { casual worker } 12 \\
(32.43 \%), \\
\text { entrepreneur } 7 \\
(18.92 \%), \text { Private } \\
\text { sector employee } 2 \\
(5.41 \%), \text { public sector } \\
\text { employee } 1(2.70 \%), \\
\text { driver } 1(2.70 \%), \text { not } \\
\text { specified } 1(2.70 \%)\end{array}$ & $\begin{array}{c}\text { Farmer } 5(9.26 \%) \text {, trader } \\
12(22.22 \%), \text { casual } \\
\text { worker } 20(37.04 \%), \\
\text { entrepreneur } 3(5.56 \%), \\
\text { private sector employee } 6 \\
(11.11 \%), \text { public sector } \\
\text { employee } 3(5.56 \%), \\
\text { driver } 1(1.85 \%), \text { retired } 2 \\
(3.70 \%), \text { unemployed } 1 \\
(1.85 \%), \text { not specified } 2 \\
(3.70)\end{array}$ & $\begin{array}{c}\text { Entrepreneur } 4 \\
(66.67 \%), \text { private } \\
\text { sector employee } 1 \\
(16.67 \%), \text { retired } 1 \\
\quad(16.67 \%)\end{array}$ & $\begin{array}{c}\text { Housewife } 2(1.85 \%), \\
\text { farmer } 12(11.11 \%), \text { trader } \\
19(17.59 \%), \text { casual worker } \\
34(31.48 \%) \text {, entrepreneur } \\
19(17.59 \%), \text { private sector } \\
\text { employee } 10(9.26 \%), \text { public } \\
\text { sector employee } 4(3.79 \%) \text {, } \\
\text { driver } 3(2.78 \%), \text { retired } 3 \\
\text { (2.78\%), unemployed } 1 \\
(0.93 \%), \text { not specified } 3 \\
(2.78)\end{array}$ \\
\hline
\end{tabular}


In the data processing phase, the related literature was analyzed by means of secondary data analysis, while the regulations on DRM and land management and administration were analyzed using content analysis. Moreover, other data and the processed information from above were analyzed by means of classificational analysis. Having developed the research's conceptual framework based on CDR concepts and the Japanese experience, the acquired data and information were then classified. The output of the analysis was the existing gaps on CDR development in the Lembang Fault area, as well as the recommendations for developing CDR in the Lembang Fault area. See Figure 6 for the methodology of this research.

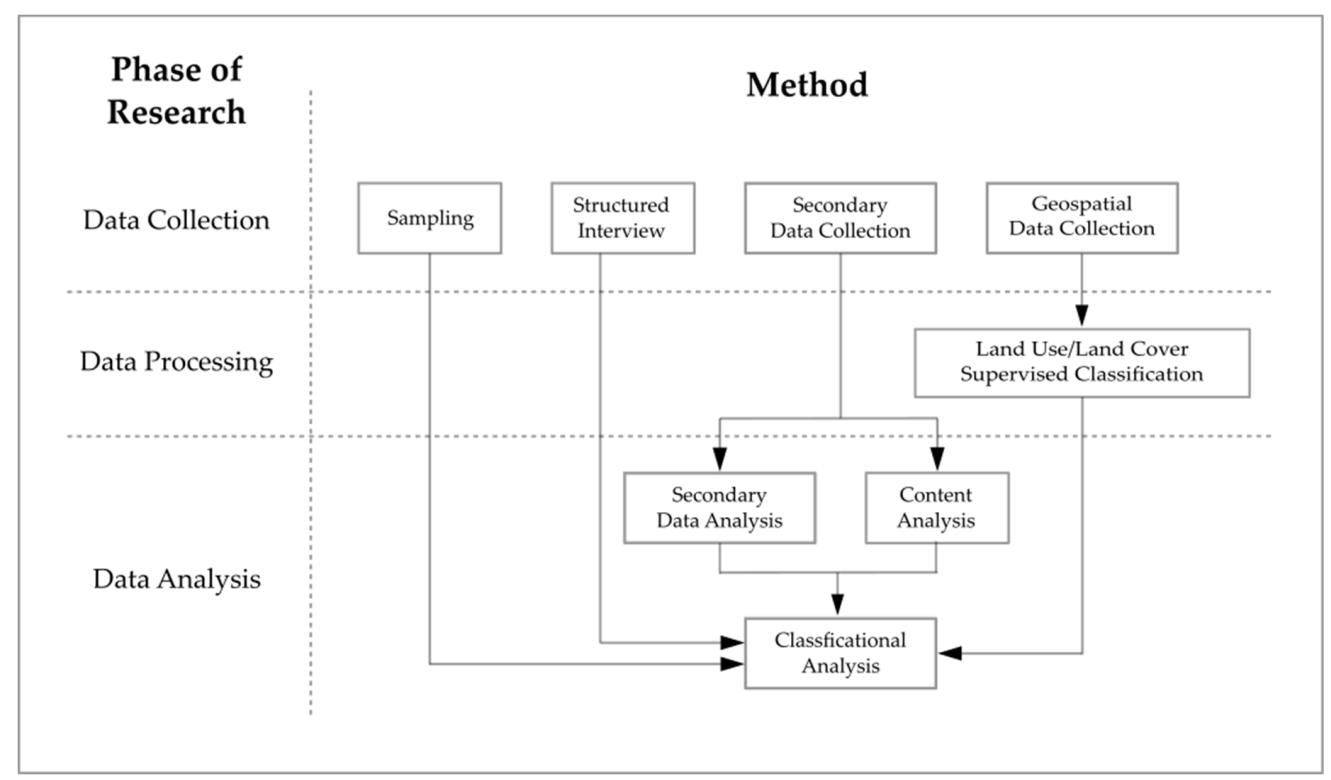

Figure 6. Methodology of the research.

\section{Theory}

In this section, the domains and their subcategories in the scope of assessment of CDR were given. The domains and their subcategories were utilized as the framework on assessment of CDR in the research highlighted in this paper. See Table 2 for the domains and subcategories for CDR assessment.

\subsection{Community Disaster Resilience}

Comprehensive assessment of CDR has been mainly carried out by considering social, economic, institutional, infrastructural, and environmental domains [1,26,34,35]. An assessment framework was proposed based on several literatures by considering local risks, vulnerabilities and the scale of the anticipated disaster [34], while another framework was developed based on several resilience indexes, namely Baseline Resilience Index for Communities, Climate Disaster Resilience Index and Community Disaster Resilience Index [12]. On the other hand, suggestions from government agencies, NGOs, community leaders, and business communities were collected for developing such a framework [26].

Social domain comprises subcategories on demography, as well as social capital and cultural characteristics $[1,26,34,35]$. Demography subcategory comprises of assessment on proportion of population's age, diffability, gender, educational level, and wealth, while social capital and cultural characteristics are defined by the quality of relationships among individuals and at the community level that contribute to community resilience, particularly concerning bonding among people and community with similar characteristics, bridging between people and community with different characteristics, and linking people and community to institutions at the higher level [34]. Risk knowledge is considered as another important factor that should be considered [1,26,35-37]. Risk knowledge comprises of knowledge on types and levels of hazard and indigenous knowledge [1,26,35]. Addition- 
ally, past disaster experience [36,37] and the level of training and education on DRM [1] are considerably important for enhancing the preparedness to face natural hazards. Furthermore, it is also proposed that people capacity on DRM should be included as an assessment parameter in this domain $[1,13,35]$. In addition, it is suggested that participation $[1,26]$ and health [1] are to be included on the assessment of this domain [1,26].

Table 2. Domains and subcategories of community disaster resilience assessment.

\begin{tabular}{|c|c|}
\hline Domain & Subcategory \\
\hline Social & $\begin{array}{ll}\text { - } & \text { Demography } \\
\text { - } & \text { Social capital and cultural characteristics } \\
\text { - } & \text { Risk knowledge } \\
\text { - } & \text { Participation } \\
\text { - } & \text { People capacity on DRM }\end{array}$ \\
\hline Economic & $\begin{array}{ll}\text { - } & \text { Local economy } \\
\text { - } & \text { Individual livelihood }\end{array}$ \\
\hline Institutional & $\begin{array}{ll}\text { - } & \text { Policy and regulations } \\
\text { - } & \text { Procedures on DRM } \\
\text { - } & \text { Organized governmental services } \\
\text { - } & \text { Cooperation among government institution, NGOs, and the community }\end{array}$ \\
\hline Infrastructural & $\begin{array}{ll}\text { - } & \text { Transportation infrastructure } \\
\text { - } & \text { Disaster management infrastructure } \\
\text { - } & \text { Land use } \\
& \text { Structural design }\end{array}$ \\
\hline Environmental & $\begin{array}{ll}\text { - } & \text { Natural environment condition } \\
\text { - } & \text { Built environment condition } \\
\text { - } & \text { Lypes of disaster } \\
& \text { Levels of hazard }\end{array}$ \\
\hline $\begin{array}{l}\text { Land } \\
\text { administration }\end{array}$ & 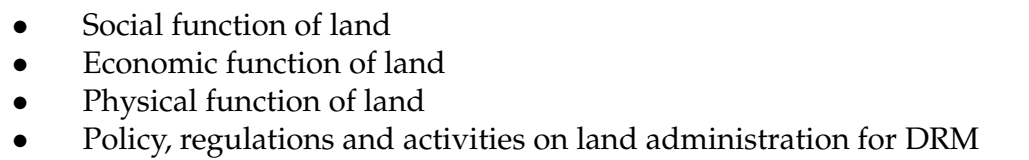 \\
\hline
\end{tabular}

From the perspective of institutional domain, the institutional capacity on DRM, namely the existence of policy, regulation, and procedures on warning and evacuation; responding and recovering from disaster [26,34,35]; as well as mitigation plans [26], are proposed to assess CDR. Additionally, participation and cooperation among government institution, NGOs, and the community [26], as well as organized governmental services [35], are also pivotal to assess CDR in this domain.

On the economic domain, the means of individual livelihood and local economy are substantially important to be assessed, while transportation infrastructure is noticeably important among the vital subcategories on infrastructural domain [26,34,35]. Disaster management infrastructure, land use, and structural design are also considered as parameters on the assessment of CDR from the infrastructural perspective [35].

For the environmental domain, there are several important assessment parameters. These parameters include the condition of the natural environment [26,34,35], the condition of the built environment [34], and types of disaster and their levels of hazard [26].

Last but not least, the research that is highlighted in this paper also analyzed the importance of data on developing CDR in the scope of DRM. This is mainly triggered by Sarker and colleagues [38], as well as Gizzi and colleagues [39], who found correlations among sound data management, DRM, and CDR. 


\subsection{Land Administration for Community Disaster Resilience}

Concerning issues on relocating people during the recovery phase to a safer place, land administration is proposed as a domain on the assessment of CDR. People who were affected by the 2018 landslide in the municipality of Sukabumi and the 2018 tsunami in the municipality of Pandeglang [28], as well as casualties of the 2004 tsunami in the municipality of Banda Aceh [29], returned to land even though the areas were already defined as restricted zones due to their proneness to the related disaster. The main reason for the fatalities caused by the 2018 landslide in the municipality of Sukabumi and the 2018 tsunami in the municipality of Pandeglang to return to their land or nearby areas was the strong connection between the people and their land [28].

Land administration is defined as a process run by the government using public or private sector agencies related to land tenure, land value, land use, and land development [40]. Land administration regulates relationship between people and land by defining rights, restrictions, and responsibilities of the people to their land [41]. The success of the mentioned process mostly depends on the existence of a sound land administration system, which is an infrastructure for implementation of land policies and land management strategies, while land management is an activity associated with the management of land to achieve sustainable development goals [40].

While land administration regulates the existing relationship, it is argued that such a relationship may be intervened. In the scope of disaster risk management, relocating people, particularly those who are affected by disaster, to a safer zone is considered as among the interventions for the people-land relationship. Furthermore, land administration may regulate the people-land relationship at every phase of disaster risk management [42]. Thus, land administration is a powerful tool to ensure a successful disaster risk management.

Furthermore, land administration plays an important role on the recovery from disaster, as well as developing CDR. The revision of spatial planning of the municipality of Banda Aceh was one of the important processes at the recovery phase of the 2004 Great Tsunami of Aceh [29]. The spatial plan was developed based on the proneness of the municipality to tsunami, which pushed the residential areas to safer grounds. At the recovery phase after the 2018 Lombok Island Great Earthquake, land readjustment was initiated to create safer neighborhoods in Lombok Island [43]. The dense settlements, unreliable houses, and inadequate access to evacuation areas were among the main causes of casualties in the aforementioned earthquake, which became the main considerations on the performance of land readjustment [44].

A good land tenure system was proven to facilitate the disaster recovery phase, as well as to lead to a resilient community to disaster. Due to the 2004 Great Tsunami of Aceh, official land records were mostly damaged [29]. On the other hand, during the recovery phase of the 2018 Great Earthquake of Lombok Island, the land readjustment process included the first-time land registration for most of affected parcels [43].

In the scope of development of CDR, several subcategories were proposed. The subcategories are social, economic, and physical functions of land for the people and community. These subcategories were proposed based on the social, economic and physical domains of the people-land relationship [40].

\section{Results}

\subsection{Community Disaster Resilience in Lembang Fault Area}

In this section, the description of CDR in the Lembang Fault area from the perspective of the previously mentioned domains and subcategories is given. See Table 1 in Appendix A for the summary of the collected data for this research.

In social domain, while statistics on gender in the four districts were available, population's age data only existed for the Sukasari district. On the other hand, statistics on diffability, educational level, and wealth at the district level were not available. In the Sukasari district, the population was dominated by a productive age group between 20and 60-year-old. The proportion of women and men in the four districts is equal. On the 
other hand, in the Sukasari and Lembang districts, more than $30 \%$ of population were senior high school graduates, while the proportion of elementary school graduates who did not pursue further education in Parongpong and the Cisarua district is the highest in the latter mentioned districts.

The degree of social capital of people in the Lembang Fault area was noticeably high. According to Tjokropandojo and colleagues [45], the social capital of people who live in the Lembang Fault area is significantly high, particularly concerning bonding and bridging. On the other hand, the degree of linking in the scope of social capital concerning DRM is very low, as $8.33 \%$ of respondents interacted with the government institutions and NGOs in the scope of DRM.

Concerning the knowledge on the proneness of the area, $67.59 \%$ of the respondents understood the risk of living in the Lembang Fault area. Furthermore, 37.04\% of the respondents acquired such an information from mass media, such as television, while $29.63 \%$ of the respondents learned the information from social media. The knowledge has also been passed on to the people in the area as $29.63 \%$ of the respondents got the information from their neighbors and/or personal experience. There are also indigenous knowledge concerning the proneness of the area in several folktales and folk songs, as well as geographic feature names [46]. Nonetheless, as the knowledge is represented in the form of symbols, people can hardly interpret such symbols especially with regard to DRM [46]. Moreover, training and education level of the respondents was low as there were only 20 respondents or $18.52 \%$ of the total respondents acquired education from governments, schools, and/or NGOs. The degree of participation of the respondents on disaster risk management is considerably low. Only $25.93 \%$ of the respondents agreed that disaster mitigation should be carried out by means of environmental protection, disaster response simulation, disaster risk management education, and promoting disaster-resistant structure. However, $16.67 \%$ of the respondents thought that it is not necessary to perform disaster mitigation, while $50.93 \%$ of the respondents did not know whether such an effort is necessary. Such an attitude led to a low degree of participation as $64.81 \%$ of the respondents thought that there is nothing they could do to mitigate and/or to respond to the disaster.

The people's capacity on DRM is also low. The majority of the respondents $(47.22 \%)$ had no clue on how to deal with the existing hazards, while $20.37 \%$ of the respondents thought that evacuation to the safe area outside the Lembang Fault area is possible. Considering the extent of the Lembang Fault area and the existing hazards, evacuation to a safe area outside the Lembang Fault area is almost impossible in a short time. Furthermore, $13.89 \%$ of the respondents thought that it is enough to perform building evacuation, while $1.85 \%$ of the respondents chose to stay at home during the disaster. Unfortunately, $17.59 \%$ of the respondents expressed that they believe their neighborhoods are safe from various types of disasters. It can be concluded that the knowledge of the respondents on the matter was very limited and inadequate to response the possible disaster in the area.

The health condition of the respondents was considerably good. Only 20 respondents (24.17\%) experienced various severe illnesses in the past.

During the fieldwork of the highlighted research, the information on past disaster experience was also collected, with $96.30 \%$ of the respondents experiencing earthquake, landslide, flood, volcanic eruption, and typhoon in the area, while $21.30 \%$ of the respondents experienced disaster occurrence in other areas. Half (50\%) of the respondents who experienced earthquakes in the area feel anxious due to the events, $12.96 \%$ were more alert on the proneness of the earthquakes, while $31.48 \%$ of the respondents were getting used to the disaster. Nonetheless, the scales of disaster events were considerably low [30,46,47], except in the Muril Quarter which experienced the 3.3 Mw earthquake in 2011 [46]. Most of Muril Quarter residents were still experiencing psychological trauma due to the earthquake.

In the economic domain, there are two subcategories that are considered to develop $\mathrm{CDR}$, namely the local economy and individual livelihood. The local economy is defined as the degree of diversity of industries, which reveals the ability to revitalize the local economy, while individual livelihood is the ability of people to seek suitable employment 
that comprises of two subcategories, namely the availability of jobs to suit dignity and the availability of alternate employment [34]. In Cisarua, Lembang, and Parongpong districts, the local economy was spearheaded by the agricultural sector. In Lembang and Parongpong districts, trading, particularly in the scope of tourism, also dominated citizens' employment. On the other hand, in the Sukasari district, $57.56 \%$ of the people were employed in the services sector. In the latter, $28.70 \%$ of the respondents were laborers, while $18.52 \%, 16.67 \%$, and $11.11 \%$ were traders, entrepreneurs, and farmers, respectively. This reveals that there was less opportunity in the agricultural sector compared to that of the industrial, trading, and entrepreneurship sectors.

DRM in Indonesia is regulated by Act Number 24 of 2007, concerning disaster management. The act was applied by the local governments in the Lembang Fault area, particularly in the municipality of Western Bandungby promulgating the 2012 Municipal Decree on Spatial Plan, which plans the designation of disaster-prone areas, as well as evacuation zone and routes, for DRM in the Lembang Fault area. Moreover, the 2013 Municipal Decree on DRM was also enacted to regulate DRM in the municipality in general, and especially in the Lembang Fault area. On the other hand, DRM procedures were not publicly available, while organized governmental services did not exist in the four districts. However, several NGOs promoted DRM activities, which encourage both the government institutions and the communities to collaborate. Nonetheless, because there were only $22.72 \%$ of the respondents who acquired risk knowledge from such activities, it could be concluded that the coverage of the activities was considerably low.

Inter-district road networks in the case study area are basically adequate to facilitate people's mobilization. However, $54.63 \%$ of the respondents mentioned that there is no adequate evacuation spot, while $5.56 \%$ of the respondents did not know about such an infrastructure. Moreover, $43.52 \%$ of respondents stated that access to the available DRM infrastructure was adequate, while $1.85 \%$ of the respondents mentioned that the access to DRM infrastructure was inadequate. Unfortunately, $50.92 \%$ of the respondents did not know whether there is access to the existing DRM infrastructure.

In 2021, the land use/land cover of the Lembang Fault area is dominated by agriculture areas and forest, which covers $35.85 \%$ and $35.00 \%$ of the case study area, respectively. See Table 3 for the extent and proportion of land use/land cover between 2019 and 2021. On the house structure of the respondents, $87.04 \%$ of the respondents' houses were made of brick and/or concrete. However, the survey did not collect specific information concerning the vulnerability of the houses to disaster, although $24.07 \%$ of the respondents agreed that there should be structural reinforcement of their houses.

Table 3. Land use/land cover change between 2019 and 2021.

\begin{tabular}{|c|c|c|c|c|c|c|c|c|c|}
\hline \multirow{3}{*}{ LULC } & \multirow{2}{*}{\multicolumn{3}{|c|}{ Extent $\left(\mathbf{k m}^{2}\right)$}} & \multicolumn{6}{|c|}{ Land Use/Land Cover Change } \\
\hline & & & & \multicolumn{2}{|c|}{ 2019-2020 } & \multicolumn{2}{|c|}{ 2020-2021 } & \multicolumn{2}{|c|}{ 2019-2021 } \\
\hline & 2019 & 2020 & 2021 & $\begin{array}{l}\text { Extent } \\
\left(\mathrm{km}^{2}\right)\end{array}$ & $\%$ & $\begin{array}{l}\text { Extent } \\
\left(\mathbf{k m}^{2}\right)\end{array}$ & $\%$ & $\begin{array}{l}\text { Extent } \\
\left(\mathbf{k m}^{2}\right)\end{array}$ & $\%$ \\
\hline $\begin{array}{c}\text { Body of } \\
\text { Water }\end{array}$ & 25,111 & 27,468 & 25,844 & 2357 & $9.39 \%$ & -1624 & $-5.91 \%$ & 733 & $2.92 \%$ \\
\hline Settlement & 279,443 & 298,080 & 316,919 & 18,637 & $6.67 \%$ & 18,839 & $6.32 \%$ & 37,476 & $13.41 \%$ \\
\hline Forest & 546,007 & 528,249 & 411,644 & $-17,758$ & $-3.25 \%$ & $-116,605$ & $-22.07 \%$ & $-134,363$ & $-24.61 \%$ \\
\hline Agriculture & 375,118 & 385,788 & 421,646 & 10,670 & $2.84 \%$ & 35,858 & $9.29 \%$ & 46,528 & $12.40 \%$ \\
\hline
\end{tabular}

While the survey did not collect further information on the condition of natural and built environment, the extent of residential and agricultural areas between 2019 and 2021 increased by 34,476 square $\mathrm{km}$ (or $13.41 \%$ ) and 46,528 square $\mathrm{km}$ (or $12.40 \%$ ), respectively. On the other hand, the extent of the forest between 2019 and 2021 decreased from 546,007 square $\mathrm{km}$ to 411,644 square $\mathrm{km}$ (or $24.61 \%$ ) of the total extent of the forest. See Table 3 for details. Furthermore, according to the survey, 50\% of the respondents stated 
that their neighborhood is prone to earthquake, specifically due to Lembang Fault, while $19.44 \%$ of the respondents mentioned that their neighborhood is also prone to landslide and flood. As mentioned in the Introduction, the level of hazard, particularly concerning earthquake, in the Lembang Fault area is considerably high.

On land administration domain, it is argued that the social connection between the people and their land was high. This is because most respondents lived in the Lembang Fault area for more than 10 years. The economic connection between the people and their land was also high, as $63.89 \%$ of the respondents' place of works were less than $5 \mathrm{~km}$. As the land use/land cover of the Lembang Fault area between 2019 and 2021 is dominated by agriculture land and forest, the dependency of the people living in the Lembang Fault area to their environment was also high. Furthermore, there are also policy and regulations concerning DRM-related land administration, although, based on the survey, such policy and regulations provided no impact to the people. Furthermore, the respondents agreed that there were less activities on DRM-related land administration.

\subsection{Japanese Experience on Development of Community Disaster Resilience}

This section introduces case studies of communities engaged in activities that aimed to improve community resilience, which proved successful in the face of disasters. Specifically, the case studies describe success stories on mitigation of damage by conducting communitybased disaster risk management activities during normal times, as well as legalizing disaster warning zones for landslides that affected the former activities.

\subsubsection{Land Management for the Prevention of Sediment Disaster in Japan}

In Japan, the Act on Sediment Disaster Countermeasures for Sediment Disaster Prone Areas was enacted as a legal regulation on sediment disasters. The Sediment Disaster Prevention Act identifies areas whereby sediment disasters are likely to occur and prescribes soft measures, such as the establishment of warning and evacuation systems and structural regulations for buildings. This law was enacted based on the lessons learned from the torrential rains that occurred in the Hiroshima prefecture in 1999, which resulted in 24 fatalities from 325 sediment disasters [48].

Developed for regulating disaster risk management for steep-slope collapses, landslides, and debris flows, the act provides the following:

- Public awareness of areas at risk of sediment disaster;

- Establishment of a warning and evacuation system;

- Suppression of new housing development;

- Support for relocation of houses and so forth.

This research was initiated to assess the outcomes of the implementation of the Sediment Disaster Prevention Act. On the development of public awareness of areas at risk of sediment disaster, two types of areas were distinguished according to the level of hazard. The first zone refers to the sediment disaster special hazard areas, also known as the red zone, and the second zone refers to the sediment disaster hazard areas, also known as the yellow zone. After the enactment of the law, 663,258 sediment disaster hazard warning areas were established nationwide as of the end of March 2021 [49]. See Figure 7 for designation of warning areas for different types of disaster.

\subsubsection{Initiatives in the Takahama District, Ehime Prefecture}

In this section, a case study was initiated in the Takahama district of the Ehime prefecture, in which the sediment-disaster hazard warning area was established in 2015 to describe the effect of legal zoning [48]. The case study was conducted by semi-structured interviews. 


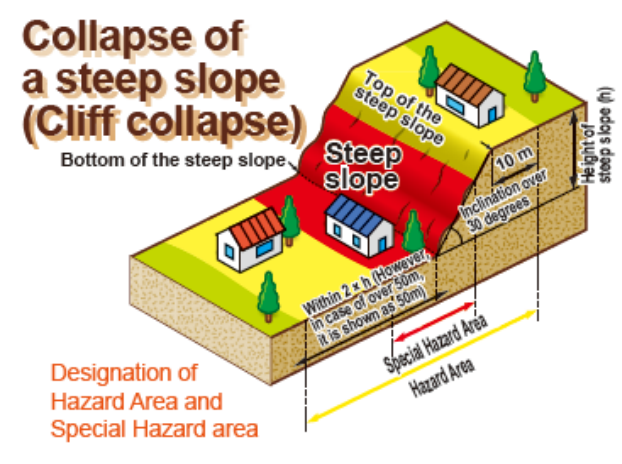

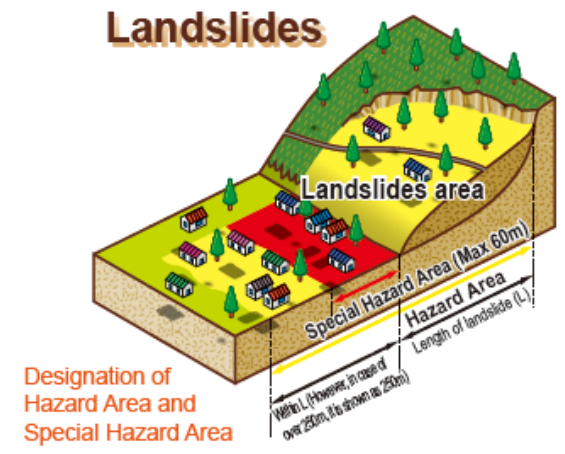

Figure 7. Designation of warning areas for different types of disaster. Areas in red are the sediment disaster special hazard areas; areas in yellow are the sediment disaster hazard areas; and areas in green are the safe areas [48].

As the Takahama district is facing the sea, the Tsunami inundation area (of $1.2 \mathrm{~m}$ to $2.5 \mathrm{~m}$ in depth) is expected in $70 \%$ of the district. The topography of the area is densely populated with houses on the flat land between the sea, the main road, and the hillside, some of which are old wooden houses. In 2018, the population was about 8000 , with an ageing rate of about $35 \%$. The ageing population was another issue that was faced by the district.

In the past, the district had suffered tremendous damage from high tides. In the forecast of the damage caused by the Nankai Trough earthquake, which is feared to occur in the future, it is assumed that seismic motion may not only lead to earthquakes but also tsunami, liquefaction, and sediment disasters during heavy rainfall. In addition, in dense wooden residential areas, there is also a rising concern on fires during earthquakes.

Due to the geographical characteristics of the area, the voluntary disaster prevention organizations in the district took the lead in planning of the operation of evacuation centers and developing the basic rules for evacuation. Such an evacuation was expected to include the participation of the whole community, including primary and secondary schools, police, firefighters, and companies [50]. See Figure 8 for cooperation system based on voluntary disaster prevention organizations.

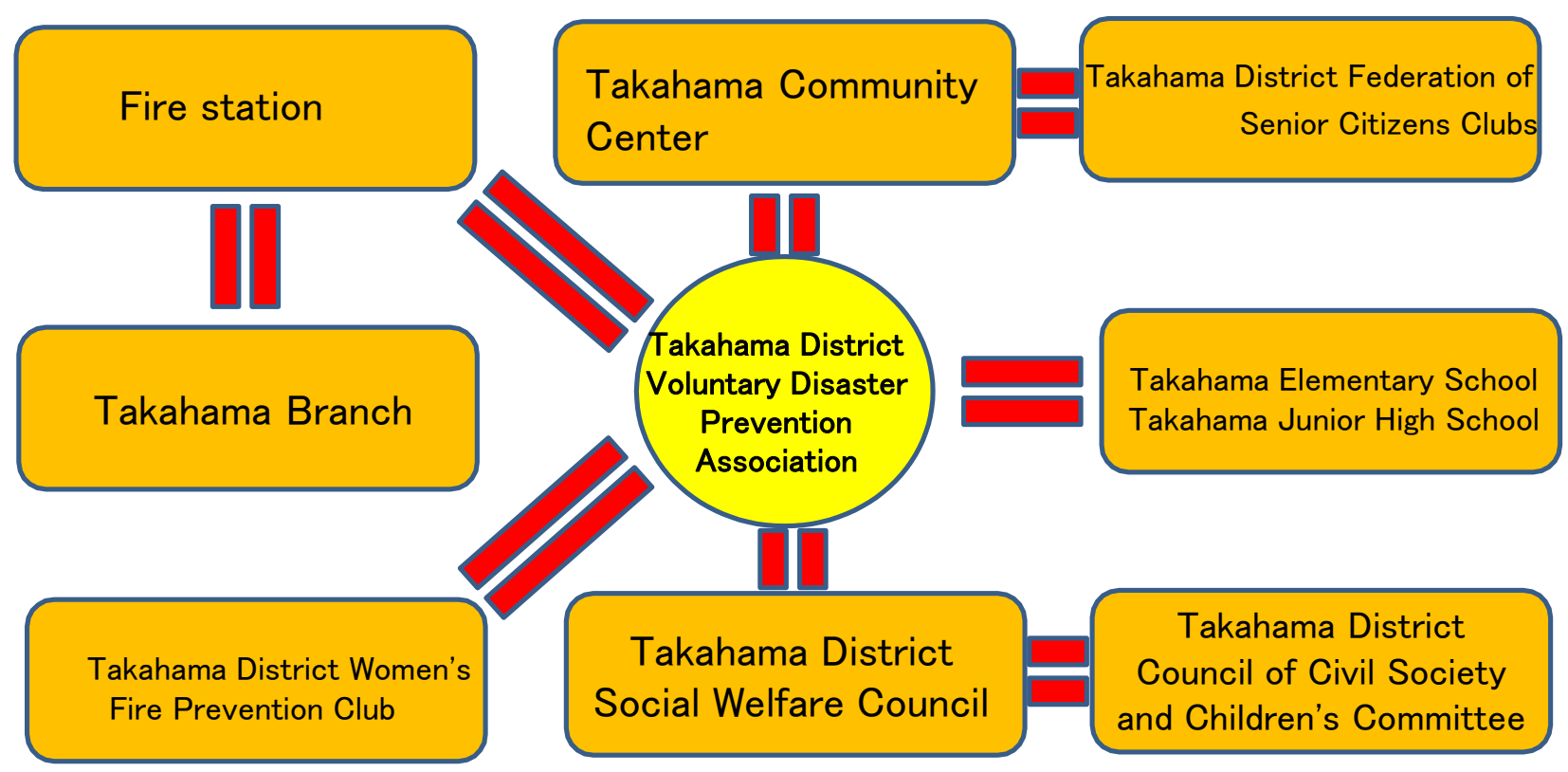

Figure 8. Cooperation system based on voluntary disaster prevention organizations [51]. 
One of the important features of the research project was that the local disaster drills were held on the same day as the Sunday school visit day of the elementary and junior high schools, with the cooperation of local residents, children, students, and their parents. The disaster drills held in 2015 were attended by about 1000 local residents, who were informed about the contents of the district disaster prevention plan and the rules for evacuation shelters. See Figure 9 for disaster drills that included the participation of people with various professions from various generation. In addition, the junior high school students took the initiative to participate in the management of the evacuation shelters, encouraging them to change their mindset from being the ones to be helped to being the ones to help.

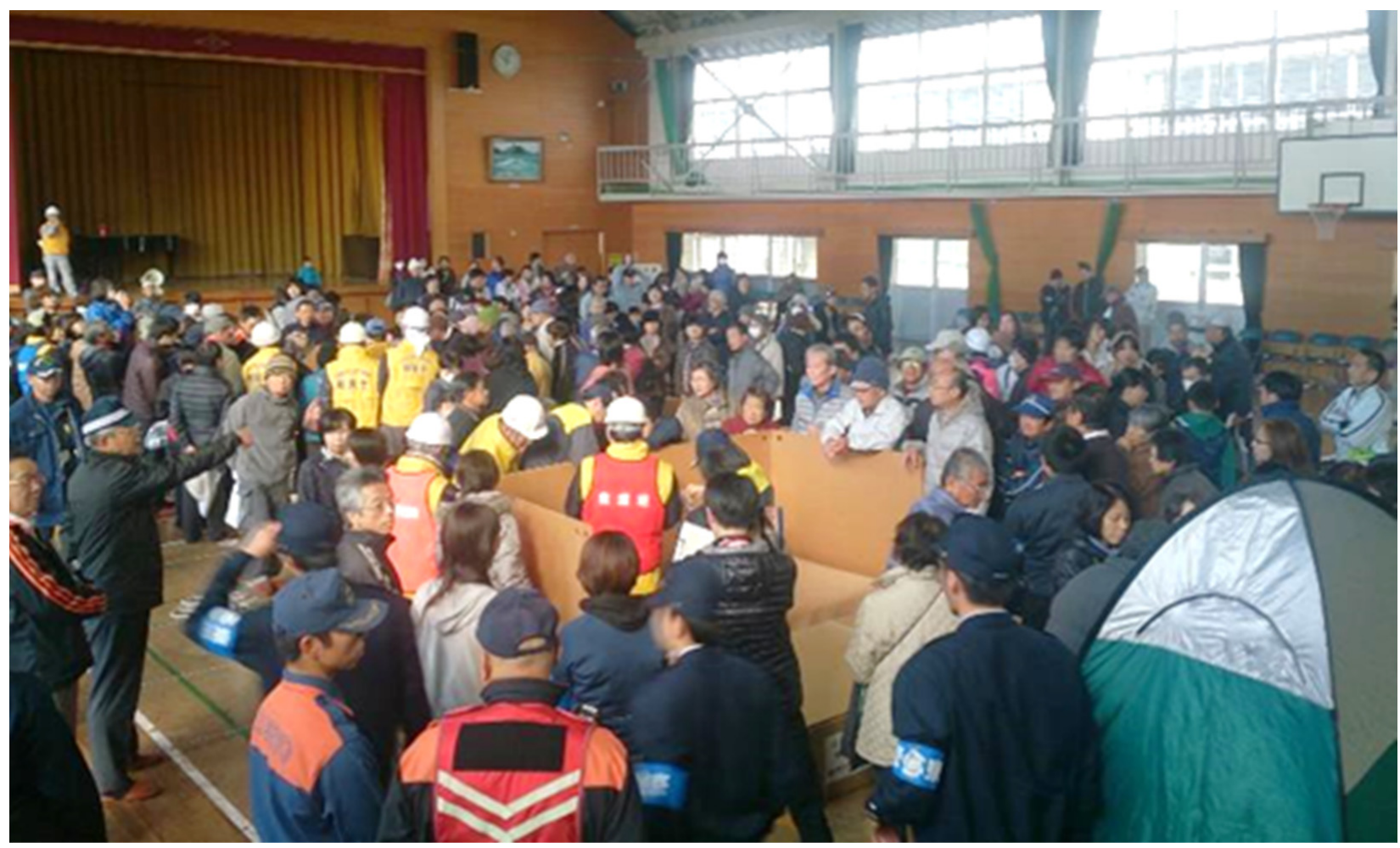

Figure 9. Disaster drills that included the participation of people with various professions from various generations [51].

\subsubsection{July 2018 Torrential Rains Disaster and the Effect of Areal Regulation}

In the Takahama District, drills were initially conducted with the purpose of evacuation from the coastal areas to higher grounds. Such a scheme was developed based on the past experience of high-tide disasters and the expected damage caused by the Nankai Trough earthquake, which is expected to cause enormous damage. In other words, maritime threats were the most feared hazard in the district.

However, in 2015, the Ehime prefecture set up a sediment disaster warning area in the district. This fact had a great impact on the area. In other words, they did not expect a sediment disaster to occur in their area. Before the establishment of the zone, the evacuation strategy of the community was to evacuate from the coastal area to higher ground. However, due to the establishment of the mentioned zone, it was realized that the designated evacuation zones at the higher grounds of the area were prone to sediment disasters.

This areal regulation led to new activities in the region. First, a response plan was developed for each type of disaster. Second, the participatory disaster prevention map, prepared for marine-related hazards, was revised, and a new evacuation site was set up for sediment disasters. The new evacuation sites were marked on the map and communicated to the residents in the district. 
This new approach helped to successfully avoid any casualty in the Takahama district during the sediment disaster caused by a prolonged heavy rainfall in July 2018. Known as the West Japan Torrential Rains, the disaster caused a large number of casualties, especially in Okayama, Hiroshima, and Ehime prefectures, while the number of evacuees reached 40,000 , i.e., its peak [52].

In the morning of 6 July 2018, the day before the damage occurred, a sediment disaster warning was issued for the whole of Matsuyama City. This information triggered the voluntary disaster prevention organizations to start patrolling the district in the afternoon. During the patrol, they noticed an anomaly and confirmed a mudslide, which became the main reason to perform door-to-door socialization on the evacuation from around 6 p.m.

Furthermore, due to the sense of imminence of the disaster, the residents requested Matsuyama City to issue an evacuation order. At 9 p.m., an evacuation order was issued for the area and a warning to evacuate was also issued by the local government. As a result, the information was delivered through a variety of channels, from the perspective of local residents who were familiar with the situation in their area, and from the government, which had the means to send out a simultaneous announcement.

After that, the rain reached its peak from around 10 p.m. to midnight and mudslides, as well as debris flows, which occurred in 35 places in the district before dawn on the 7 July 2018. See Figure 10 for debris flowed into a residential area in the Takahama district. Although it was the first time for the district to experience a sediment disaster, the evacuation was carried out without waiting for instructions from the government and everyone was safe.

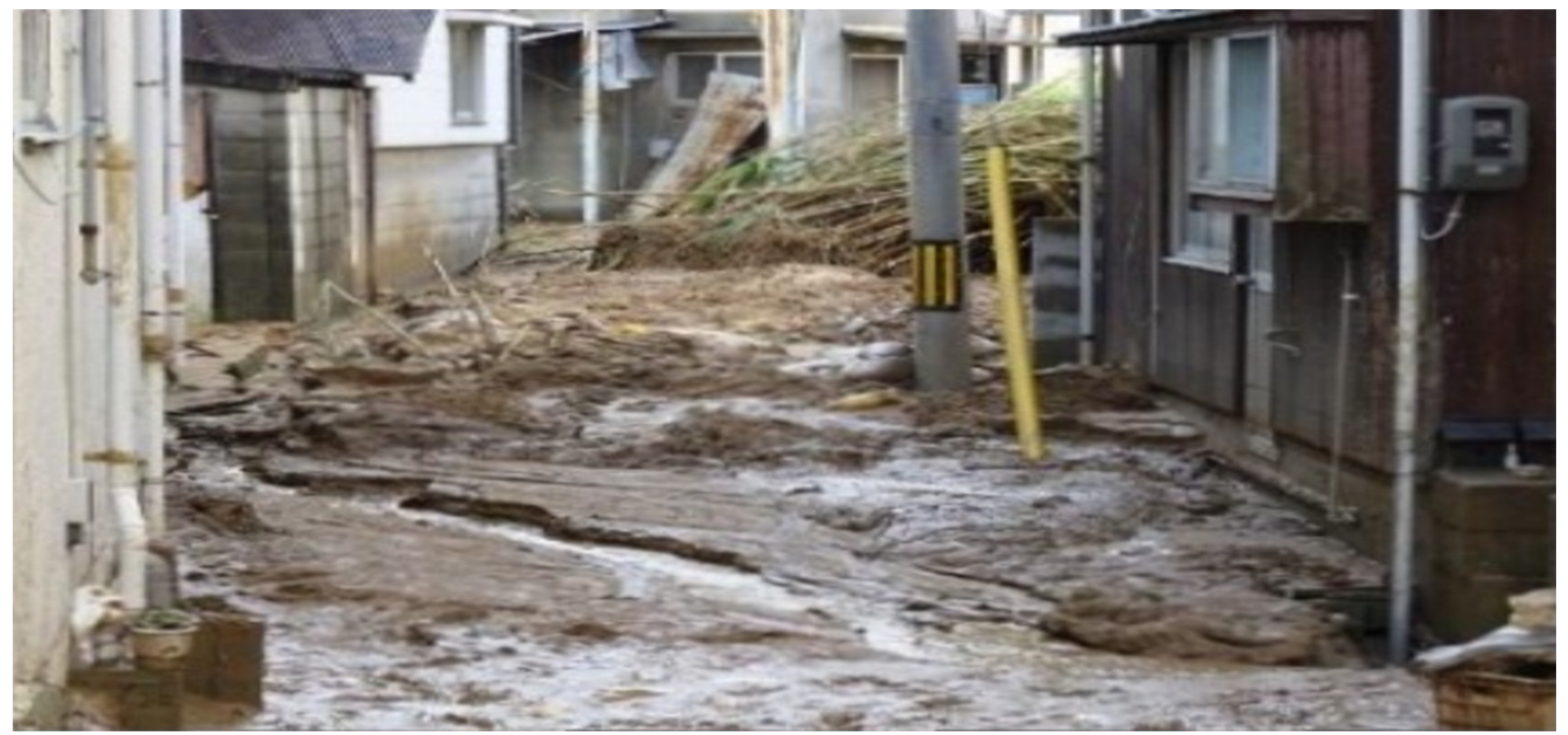

Figure 10. Debris flowed into a residential area in the Takahama district [51].

This cooperation was possible because of the mutual understanding of the strengths of the voluntary disaster prevention organizations, which know the local community well, and the strengths possessed by the government. The government is able to deliver information such as evacuation advisories to many residents at the same time through area e-mails and disaster prevention administrative radios. This is a great advantage that the residents do not have.

The voluntary disaster prevention organizations played a central role in the subsequent recovery and reconstruction of the district. The information was disseminated to the residents in the district using circular boards. For example, information on how to dispose 
of debris and rubble, according to the phase of life reconstruction, was distributed, as well as information on the support from the government for disaster victims.

Even during the typhoons that struck frequently during the subsequent recovery process, calm decisions were made based on the response measures for each disaster type, and evacuation notices were issued according to the characteristics of the hazard.

\section{Discussion}

In this section, the development of CDR in the Lembang Fault area is discussed. The themes of the discussion are the low level of participation and capacity on DRM, as well as the importance of government intervention on developing CDR that leads to the need of a sound land management strategy and land administration system. Furthermore, the discussion on the CDR development strategy based on demographic data and the importance of an organized community, as well as the strategy to allow the community to bounce back from the disaster, are also given in this section. Additionally, an issue on data management for supporting the development of CDR is also discussed in this section.

The level of people's participation and capacity on DRM acts as the core of CDR development, especially in the Lembang Fault area. Subcategories and sub-subcategories of social domain are mainly utilized to assess the resilience of the community in the event of a disaster [34]. While community's demographic profile, risk knowledge, and social capital provides information concerning characteristics of the community acts as the basis on DRM strategy development [37], it is people's participation and capacity on DRM that determine the ability of the community to utilize their characteristics to develop resilience to disaster $[1,13]$.

Unfortunately, the levels of people's participation and capacity on DRM in the Lembang Fault area were noticeably low. The low level of people's participation and capacity on DRM may be caused by several factors, namely the low level of training and education, linking of social capital, and past disaster experience. Additionally, the form of indigenous knowledge may also contribute to such circumstances.

The argument on the low coverage of training and education from governments, universtities, and NGOs in the Lembang Fault area was developed based on the response of the respondents who were expecting to be involved in such drills. As explained by Patel and colleagues [1], training and education are important factors to develop local knowledge and capacity, as well as to respond to an emergency. Moreover, based on the Japanese experience, the responsiveness of the community was a result of local disaster drills. As described in Section 4.2.2, the local drills were attended by residents with various characteristics and backgrounds, while in Lembang Fault, education was only provided to the community leaders, few heads of families, and few primary school children. During the drills, the existing hazards and the evacuation plan, including the division of tasks among citizens, were explained, followed by the simulation of the evacuation. Most importantly, the drills should be included within a routine education curriculum $[1,8]$, which did not exist in the Lembang Fault area. On the other hand, there was evidence that the capacity of universities and NGOs to provide training and education on DRM was limited.

The low level of linking of social capital may also limit people's participation and capacity on DRM in the Lembang Fault area. The linking of the social capital sub-subcategory defines the ability of the community to connect itself to a higher ranked institution to acquire support concerning DRM $[1,34]$. This may explain the cause of the lack of training and education on DRM in the Lembang Fault area as the community cannot advocate and connect itself to the government, universities, and NGOs to acquire their support. Therefore, the low level of linking of social capital may be an indirect cause of the low level of people's capacity on DRM. Furthermore, the inability of the community to perform self-advocacy may directly be linked to a low level of participation [1].

In the Lembang Fault area, the correlation between past disaster experience and the level of participation and capacity on DRM is high. Past small-scale disaster experience may only lead to the assumption that people may be able to cope with any future event and it is 
not necessary to be prepared [36]. Such an assumption is basically reflected in the findings in the Lembang Fault area. According to Becker and colleagues [36], a normalization of bias is required to enhance the awareness of the people, which in turn, may enhance the level of participation and capacity on DRM in the Lembang Fault area. Particularly in the Muril Quarter, the residents of the Muril Quarter were still traumatized due to the impact of the 2011 earthquake [46]. Unfortunately, trauma healing activity in the Muril Quarter was not carried out [46].

Concerning the correlation between the existence of indigenous knowledge and the level of people's participation and capacity on DRM, the ability of the people to interpret such knowledge is important. As mentioned earlier, there were only few people who were able to interpret the symbols in folktales and folk songs [46]. As explained by Patel and colleagues [1], any knowledge regarding DRM should be understood by the people in order to develop CDR.

It is argued that government intervention will be crucial on the development of CDR in the Lembang Fault area, as such an intervention will act as one of the triggers on increasing people's participation and capacity on DRM [1]. The Japanese experience provided a good example for this argument. The government provided training and education for the people of the Takahama district. In addition, the government assigned an NGO to assist the citizens during emergency response. This reduced the number of fatalities during the 2018 Torrential Rains Disaster.

Furthermore, the government is expected to establish legal and physical infrastructures, as well as to provide services to the community, to assist the implementation of DRM and to develop CDR. Involvement of government, particularly the development of DRM-related infrastructures and provision of DRM-related services, is considerably important to improve the capability of the community to quickly respond to the disaster occurrence [1]. Although the spatial plan limits the development in the Lembang Fault area, the extent of agricultural and settlement areas was continuously rising, which reveals the lack of implementation of the plan. Implementation and monitoring of building code are also expected to be carried out, as the respondents highlighted the need to perform structural reinforcement of their houses. DRM procedures should also be established by the government, as required by the 2013 Municipal Decree on DRM. Moreover, the respondents stated that the quantity and quality of DRM infrastructure in the Lembang Fault area are expected to be enhanced. Based on the Japanese experience, such developments may only be initiated by the government.

Based on the Japanese experience, it is also clear that DRM-related government intervention in land management and administration is needed to develop CDR in the Lembang Fault area. The Japanese government not only enacted the basic regulations on DRM, but also regulations that specifically deal with various types of disaster, particularly sediment disaster. Moreover, as mentioned in the Theory Section, a sound land tenure system also contributed to the successful disaster recovery phase in the past, while spatial planning and land readjustment also acted as the means to develop CDR, as the main objective of the mentioned activities during disaster recovery phase was to create a disaster-resilient settlement area $[29,39,40]$. Moreover, in Japan, the Sediment Disaster Prevention Act urges the establishment of sediment disaster-prone areas, which acts as one of land management strategies that is implemented by land administration. From the above examples, a sound land management strategy that is equipped with a good land administration system is expected to be established to develop CDR in the Lembang Fault area. In fact, land management and administration act as the core of DRM and development of CDR $[29,39,40]$.

Furthermore, from the case study of the Lembang Fault area, land management strategy and land administration are expected to be developed based on the social, economic, and environmental characteristics of the case study area. Based on the Japanese experience on the implementation the Sediment Disaster Prevention Act, land administration was performed by considering the social capital of people of the Takahama district, particularly on bridging and linking, catalyzed by the voluntary disaster prevention organizations. 
Moreover, the environmental characteristics of the Takahama district played an important role in defining evacuation areas from high tides. After the enactment of the Sediment Disaster Prevention Act, new evacuation zones were established by considering types of hazards in the mentioned district.

Considering the role of the voluntary disaster prevention organizations, it is also important to highlight the need of an organize community to develop CDR. Based on the Japanese experience, the involvement of an NGO to provide warning on the near future disaster event, as well as assisting the citizens to perform evacuation to the safe area, was one of the crucial factors to reduce fatality. From the survey, the vast coverage of the Lembang Fault area could not be covered by the NGOs that performed their activities in the mentioned area. In addition, universities and NGOs had a limited capacity to provide services concerning DRM in the Lembang Fault area. Given the level of people's participation and capacity on DRM in the case study area can be improved, the establishment of voluntary disaster prevention organizations can be encouraged in every neighborhood. Thus, DRM in each neighborhood in the Lembang Fault area may be performed by the local community. Furthermore, the organized community may also link itself to the government. Particularly in the province of Western Java, such a proposal is in accordance with the provincial government program on the development of a disaster-resistant village. The development of an organized community is imperative to ensure a successful DRM [1].

The strategy to allow the community to bounce back from the disaster is expected to be developed. From the Japanese experience, which is also backed by Patel and colleagues [1], the development of CDR is expected to allow the community to bounce back with minimum external support. In Cisarua, Parongpong, and Lembang districts, people were mostly employed in the agricultural sector. The disaster may interrupt agricultural activities which, in turn, may disrupt the supply of groceries to the disaster-affected areas and even beyond those areas. It is, therefore, important to develop a strategy to allow the people to quickly return to their fields. On the other hand, a different strategy should be developed in the Sukasari district. This is mainly because most people in the mentioned districts were employed in services area, which may be malfunctioning during a certain period after the disaster occurrence. Thus, promoting economic resilience to disaster is substantially important [1,34,35].

Specific CDR development and DRM strategy may be developed based on gender and the level of education in the Lembang Fault area [1,34]. As the proportion of women and men in the Lembang Fault area is equal, CDR development and DRM strategies should consider gender-sensitive issues. This is mainly to protect the safety of women and men during the disaster response phase and the transition from the disaster response phase to the disaster recovery phase. Additionally, by considering the level of education in each district, DRM education may be effective to be performed on elementary level as most people were elementary school graduates. For the Lembang and Sukasari districts, further DRM education may be given at high school, as more than $30 \%$ of the citizens of the districts were high school graduates. However, the number of high school graduates in Cisarua and Parongpong districts was considerably low, which will decrease the coverage of DRM education given that education in the latter districts is given at high school. Therefore, there is a need to develop a community-based curricula on DRM training and education. The demographic data may also influence the level of DRM education that will be given to ensure the success of the program. This proposal was basically developed based on the Japanese experience of dealing with the demography of the people, particularly the ageing of the population.

To further develop DRM based on CDR in the Lembang Fault area, it is expected that the baseline data should be completed, particularly on demography [34]. As described in the findings section, data on the population's age, diffability, and wealth were not available. From the Japanese experience, the ageing population has become an obstacle to DRM. Thus, data collection on age is expected to be completed. Moreover, the number of diffable people is expected to be identified, as such data will provide an important 
input on the development of CDR-based DRM from the perspective of diffable people. Additionally, data on wealth is considerably important particularly to assess the capacity of the community to bounce back from the disaster.

After performing analysis that involved an enormous volume of data, it can be suggested that big data management may be beneficial on CDR development. Big data management may be valuable to mitigate the risks and to study the impacts of disaster, while it also improves the speed and effectiveness of linkages between disaster information and systemic response [38]. Additionally, big data management is proven to assist the provision of training and education at the perfect time, which may lead to the enhanced risk perception, as well as participation and capacity of people on DRM [39]. This may explain the low level of people's participation and capacity on DRM. The incomplete data may have hindered the ability of the government, universities, and NGOs to define the exact time to perform training and education.

\section{Conclusions}

The development of CDR in the Lembang Fault area is principally possible. The concept on CDR provides a valuable guidance for such a development. However, it is important to perform a cross domain analysis to ensure the definition of appropriate strategies. Inclusion of land administration domain, on the one hand, provides an example on cross domain analysis, while, on the other hand, it may not only act as one of the core components of DRM but also lead to development of CDR.

To develop CDR in the Lembang Fault area, people's participation and capacity on DRM are considered as the crucial factors. Based on the assessment of CDR in Lembang Fault, people's participation and capacity on DRM were low. Factors that may cause such a circumstance are the low level of training and education, linking of social capital and past disaster experience, as well as the inability of the people to interpret the indigenous knowledge.

Moreover, government intervention is essential on the development of CDR in the Lembang Fault area, particularly at disaster mitigation, response, and recovery phase. Such an intervention may be beneficial to increase the level of people's participation and DRM capacity, which may lead to the development of an organized community to address DRM issues in the smallest geospatial unit as possible. The existence of organized community on DRM may lead to the betterment of the circumstances concerning every subcategory of CDR assessment.

On the other hand, economic resilience to disaster is necessary to be developed to allow the people in the Lembang Fault area to quickly bounce back from disaster. While the research reveals the possibility to develop economic resilience against disasters in natural resources-rich areas, the conceptualizing of such a development is still expected in areas with less or even no natural resources.

Most importantly, the collection of detailed data concerning domains and subcategories of CDR assessment in the Lembang Fault area is expected to be initiated. The collection of the data will lead to the need of big data management. Big data management is expected to enhance people's participation and capacity on DRM, which, in turn, is expected to develop CDR.

To initiate the development of CDR in the Lembang Fault area, collaboration among four municipal governments is expected. Furthermore, such a collaboration is expected to be extended to include the community sector, particularly to facilitate data collection by means of crowdsourcing, as well as the academic sector to provide a solid conceptual basis, to perform analysis and to develop guidance on CDR assessment and development.

The outputs of the research highlighted in this paper are the result of assessment of community disaster resilience in a geological hazard-prone area, which is characterized by the social, economic, and environmental system of people and area of the central part of the Western Java province, Indonesia. While the concept and benchmark of CDR development that were utilized in this research were developed based on various types of disasters, as 
also suggested by Patel and colleagues [1], there are common domains, subcategories, and sub-subcategories that may be employed to develop CDR in various circumstances. Thus, the conceptual framework of the research may be implemented elsewhere by considering social, economic, and environmental characteristics of the area in question. It may require adjustments for the application of the conceptual framework beyond the case study area of the research.

While the conceptual framework of this research may be replicated elsewhere, there are limitations to this research that need improving. First, the vastness of the Lembang Fault area led to a difficulty to collect data on population in the area. Therefore, it may be valuable to perform further research in an area with a smaller spatial unit extent in order to allow the acquisition of population data. Second, the Lembang Fault area has specific social, economic, and environmental characteristics. Accordingly, further research in the case study area with different social, economic, and environmental characteristics may enrich the research on CDR development.

Author Contributions: Conceptualization, R.A., A.P.H., C.I. and I.M.; methodology, R.A., A.P.H., C.I. and I.M.; validation, R.A., C.I. and I.M.; formal analysis, R.A., A.P.H., C.I. and I.M.; investigation, A.P.H. and C.I.; resources, R.A., A.P.H., C.I. and I.M.; data curation, A.P.H.; writing-original draft preparation, R.A., A.P.H. and C.I.; writing-review and editing, R.A., A.P.H. and C.I.; visualization, A.P.H. and C.I.; supervision, R.A., C.I. and I.M.; project administration, A.P.H.; funding acquisition, A.P.H. All authors have read and agreed to the published version of the manuscript.

Funding: This research was funded by Faculty of Earth Sciences and Technology, Institut Teknologi Bandung, under the 2021 Collaboration Research Program of Faculty of Earth Sciences and Technology, Institut Teknologi Bandung. There is no funding that is associated to this paper from Institute of Education, Research and Regional Cooperation for Crisis Management Shihoku, Kagawa University. The APC was jointly funded by Institute of Education, Research and Regional Cooperation for Crisis Management Shihoku, Kagawa University, and Faculty of Earth Sciences and Technology, Institut Teknologi Bandung.

Institutional Review Board Statement: Not applicable.

Informed Consent Statement: Informed consent was obtained from all subjects involved in the study.

Data Availability Statement: Not applicable.

Acknowledgments: The authors express their gratitude to S. Hendriatiningsih, Astyka Pamumpuni, Bambang Edhi Leksono, Andri Hernandi, Asep Yusup Saptari and Ratri Widyastuti of Faculty of Earth Sciences and Technology, Institut Teknologi Bandung, for their contributions to the research. In addition, the authors thank Yoshiyuki Kaneda of Institut of Education, Research and Regional Cooperation for Crisis Management Shikoku, Kagawa University, for his valuable contribution on this research, as well as for promoting collaboration between Kagawa University and Institut Teknologi Bandung.

Conflicts of Interest: The authors declare no conflict of interest. 


\section{Appendix A}

Table 1. The summary of the collected data ${ }^{1}$.

\begin{tabular}{|c|c|c|c|c|c|c|c|}
\hline Domain & Subcategory & Subsubcategory & $\begin{array}{c}\text { District of } \\
\text { Parongpong }\end{array}$ & District of Cisarua & District of Lembang & District of Sukasari & Overall \\
\hline \multirow[t]{6}{*}{ Social } & \multirow[t]{6}{*}{ Demography } & Age & No data & No data & No data & $\begin{array}{l}\text { District level: child } \\
14.69 \% \text {, adolesence } \\
15.16 \% \text {, adult } 57.51 \% \text {, } \\
\text { senior } 12.64 \% \text { [53] }\end{array}$ & No data \\
\hline & & Diffability & No data & No data & No data & No data & No data \\
\hline & & Gender & $\begin{array}{c}\text { District level: male } \\
56,693(50.80 \%) \text {, female } \\
54,897(49.20 \%)[54]\end{array}$ & $\begin{array}{c}\text { District level: male } \\
\text { 37,230 (50.20\%), female } \\
36,926(49.80 \%)[55]\end{array}$ & $\begin{array}{c}\text { District level: male } \\
100,035(51.42 \%) \\
\text { female } 94,525(48.58 \%) \\
{[56]}\end{array}$ & $\begin{array}{c}\text { District level: male } \\
\text { 38,450 (49.97\%), female } \\
38,492(50.03 \%) \text { [53] }\end{array}$ & Not collected \\
\hline & & $\begin{array}{l}\text { Educational level } \\
\text { above 10-year-old }\end{array}$ & $\begin{array}{c}\text { District level: none } \\
11.46 \% \text {, primary } \\
34.52 \% \text {, junior high } \\
25.01 \% \text {, senior high } \\
19.74 \% \text {, higher } \\
\text { education } 9.27 \% \text { [54] }\end{array}$ & $\begin{array}{c}\text { District level: none } \\
31.84 \% \text {, primary } \\
31.82 \% \text {, junior high } \\
15.98 \% \text {, senior high } \\
16.22 \% \text {, higher } \\
\text { education } 4.14 \% \text { [55] }\end{array}$ & $\begin{array}{c}\text { District level: none } \\
12.04 \% \text {, primary } \\
26.74 \% \text {, junior high } \\
25.81 \% \text {, senior high } \\
30.50 \% \text {, higher } \\
\text { education } 4.91 \% \text { [56] }\end{array}$ & $\begin{array}{c}\text { District level: none } \\
19.05 \% \text {, primary } \\
16.52 \% \text {, junior high } \\
19.87 \% \text {, senior high } \\
34.53 \% \text {, higher } \\
\text { education } 10.03 \% \text { [57] }\end{array}$ & Not collected \\
\hline & & Wealth & No data & No data & No data & No data & No data \\
\hline & & $\begin{array}{l}\text { Health: serious } \\
\text { illness }^{2}\end{array}$ & $\begin{array}{c}\text { Asthma } 2(18.18 \%), \\
\text { hyperthension } 1 \\
(9.09 \%), \text { heart-related } 1 \\
(9.09 \%), \text { lung-related } 1 \\
(9.09 \%), \text { none } 7 \\
(63.64 \%)\end{array}$ & $\begin{array}{c}\text { Indigestion } 3(8.11 \%), \\
\text { asthma } 2(5.41 \%), \\
\text { thypoid } 1(2.70 \%), \\
\text { allergy } 1(2.70 \%), \text { none } \\
30(81.08 \%)\end{array}$ & $\begin{array}{c}\text { Indigestion } 5(9.26 \%), \\
\text { thypoid } 3(5.56 \%), \\
\text { diabetes } 1(1.85 \%), \text { urid } \\
\text { acid } 1(1.85 \%), \\
\text { kidney-related } 1 \\
(1.85 \%), \text { lung related } 1 \\
(1.85 \%), \text { complication } 1 \\
(1.85 \%), \text { none } 41 \\
(75.93 \%)\end{array}$ & $\begin{array}{c}\text { Hyperthension } 1 \\
(16.67 \%) \text {, diabetes } 1 \\
(16.67 \%), \text { none } 4(66.67)\end{array}$ & $\begin{array}{c}\text { Indigestion } 8(7.41 \%), \\
\text { asthma } 4(3.70 \%), \\
\text { thypoid } 4(3.70 \%), \\
\text { allergy } 1(0.93 \%), \\
\text { hyperthension } 2 \\
(1.85 \%), \text { hearth-related } \\
1(0.93 \%), \text { diabetes } 2 \\
(1.85 \% \text {, urid acid } 1 \\
(0.93 \%), \text { kidney-related } \\
1(0.93 \%), \text { lung-related } \\
2(1.85 \%), \text { complication } \\
1(0.93 \%), \text { none } 82 \\
(75.93 \%)\end{array}$ \\
\hline
\end{tabular}


Table 1. Cont.

\begin{tabular}{|c|c|c|c|c|c|c|c|}
\hline Domain & Subcategory & Subsubcategory & $\begin{array}{c}\text { District of } \\
\text { Parongpong }\end{array}$ & District of Cisarua & District of Lembang & District of Sukasari & Overall \\
\hline \multirow[t]{8}{*}{ Social } & \multirow{3}{*}{$\begin{array}{l}\text { Social capital and } \\
\text { cultural } \\
\text { characteristics }\end{array}$} & Bonding & Not collected & Not collected & Not collected & Not collected & High [45] \\
\hline & & Bridging & Not collected & Not collected & Not collected & Not collected & High [45] \\
\hline & & $\begin{array}{l}\text { Linking to acquire } \\
\text { disaster-related } \\
\text { information, } \\
\text { education and/or } \\
\text { services }^{2}\end{array}$ & $\begin{array}{c}\text { government, university } \\
\text { and NGO } 6(54.55 \%), \\
\text { neighbor } 3(27.27 \%), \\
\text { news } 3(27.27 \%) \text {, social } \\
\text { media } 3(27.27 \%) \text {, none } \\
0\end{array}$ & $\begin{array}{c}\text { government, university } \\
\text { and NGO } 10(27.03 \%), \\
\text { neighbor } 10(27.03 \%), \\
\text { news } 12(32.43 \%), \\
\text { social media } 10 \\
(27.03 \%), \text { none } 7 \\
(18.92 \%)\end{array}$ & $\begin{array}{c}\text { government, university } \\
\text { and NGO } 8(14.81 \%), \\
\text { neighbor } 14(25.93 \%), \\
\text { news } 23(42.59 \%), \\
\text { social media } 18 \\
(33.33 \%), \text { none } 8 \\
(14.81 \%)\end{array}$ & $\begin{array}{c}\text { government, university } \\
\text { and NGO 0, neighbor } 5 \\
(83.33 \%) \text {, news } 2 \\
(33.33 \%) \text {, social media } \\
1(16.67 \%), \text { none } 0\end{array}$ & $\begin{array}{c}\text { government, university } \\
\text { and NGO } 24(22.22 \%), \\
\text { neighbor } 32(29.63 \%), \\
\text { news } 40(37.04 \%), \\
\text { social media } 32 \\
(29.63 \%), \text { none } 15 \\
(13.89 \%)\end{array}$ \\
\hline & \multirow[t]{3}{*}{ Risk knowledge } & $\begin{array}{l}\text { Proneness } \\
\text { knowledge }\end{array}$ & $\begin{array}{l}\text { Yes } 7(63.63 \%), \text { no } 4 \\
(36.36 \%), \text { none } 0 \text {, not } \\
\text { answering } 0\end{array}$ & $\begin{array}{l}\text { Yes } 26(70.27 \%), \text { no } 11 \\
(29.73 \%), \text { none 0, not } \\
\text { answering 0 }\end{array}$ & $\begin{array}{c}\text { Yes } 34(62.96 \%), \text { no } 16 \\
(29.63 \%), \text { none } 2 \\
(3.70 \%), \text { not answering } \\
2(3.70 \%)\end{array}$ & $\begin{array}{c}\text { Yes } 6(100 \%), \text { no } 0, \\
\text { none } 0, \text { not answering } \\
0\end{array}$ & $\begin{array}{c}\text { Yes } 73(67.59 \%), \text { no } 31 \\
(28.70 \%), \text { none } 2 \\
(1.85 \%), \text { not answering } \\
2(1.85 \%)\end{array}$ \\
\hline & & $\begin{array}{l}\text { Past disaster } \\
\text { experience }\end{array}$ & $\begin{array}{c}\text { In neighborhood } 11 \\
(100 \%), \text { other place } 10 \\
(90.91 \%)\end{array}$ & $\begin{array}{c}\text { In neighborhood } 35 \\
(94.59 \%), \text { other place } 3 \\
(8.11 \%)\end{array}$ & $\begin{array}{c}\text { In neighborhood } 52 \\
(96.30 \%), \text { other place } 7 \\
(12.96 \%)\end{array}$ & $\begin{array}{c}\text { In neighborhood } 6 \\
(100 \%) \text {, other place } 3 \\
(50.00 \%)\end{array}$ & $\begin{array}{c}\text { In neighborhood } 104 \\
(96.30 \%), \text { other place } 23 \\
(21.30 \%)\end{array}$ \\
\hline & & $\begin{array}{l}\text { Indigenous } \\
\text { knowledge }\end{array}$ & No data & No data & No data & No data & Exist $[46]$ \\
\hline & Participation & $\begin{array}{l}\text { Responsibility on } \\
\text { disaster risk } \\
\text { management }\end{array}$ & $\begin{array}{c}\text { Community } 1(9.09 \%), \\
\text { government } 1(9.09 \%), \\
\text { no idea } 10(90.91 \%), \\
\text { none } 0\end{array}$ & $\begin{array}{c}\text { Community } 6(16.22 \%), \\
\text { government } 6(16.22 \%), \\
\text { no idea } 20(54.05 \%), \\
\text { none } 7(18.92 \%)\end{array}$ & $\begin{array}{c}\text { Community } 22(40.74), \\
\text { government } 2(3.79 \%), \\
\text { no idea } 19(35.19 \%), \\
\text { none } 11(20.37 \%)\end{array}$ & $\begin{array}{c}\text { Community } 0 \\
\text { government } 0 \text {, no idea } \\
6(100 \%), \text { none } 0\end{array}$ & $\begin{array}{c}\text { Community } 29 \\
(25.93 \%), \text { government } 9 \\
(8.33 \%), \text { no idea } 55 \\
(50.93 \%), \text { none } 18 \\
(16.67 \%)\end{array}$ \\
\hline & $\begin{array}{l}\text { People capacity on } \\
\text { DRM }\end{array}$ & $\begin{array}{l}\text { Response to disaster } \\
2\end{array}$ & $\begin{array}{c}\text { Stay at home } 1(9.09 \%), \\
\text { building evacuation } 1 \\
(9.09 \%) \text {, disaster area } \\
\text { evacuation 0, no idea } \\
10(90.91 \%), \text { none } 0\end{array}$ & $\begin{array}{c}\text { Stay at home } 0, \\
\text { building evacuation } 7 \\
(18.92 \%), \text { disaster area } \\
\text { evacuation } 4(10.81 \%), \\
\text { no idea } 19(51.35 \%) \\
\text { none } 7(18.92 \%)\end{array}$ & $\begin{array}{c}\text { Stay at home } 1, \\
\text { building evacuation } 7 \\
(12.96 \%) \text {, disaster area } \\
\text { evacuation } 15(27.78 \%), \\
\text { no idea } 19(35.19 \%), \\
\text { none } 12(22.22 \%)\end{array}$ & $\begin{array}{c}\text { Stay at home } 0, \\
\text { building evacuation } 0, \\
\text { disaster area } \\
\text { evacuation } 3(50.00 \%), \\
\text { no idea } 3(50.00 \%), \\
\text { none } 0\end{array}$ & $\begin{array}{c}\text { Stay at home } 2(1.85 \%), \\
\text { building evacuation } 15 \\
(13.89 \%), \text { disaster area } \\
\text { evacuation } 22(20.37 \%), \\
\text { no idea } 51(47.22 \%), \\
\text { none } 19(17.59 \%)\end{array}$ \\
\hline
\end{tabular}


Table 1. Cont.

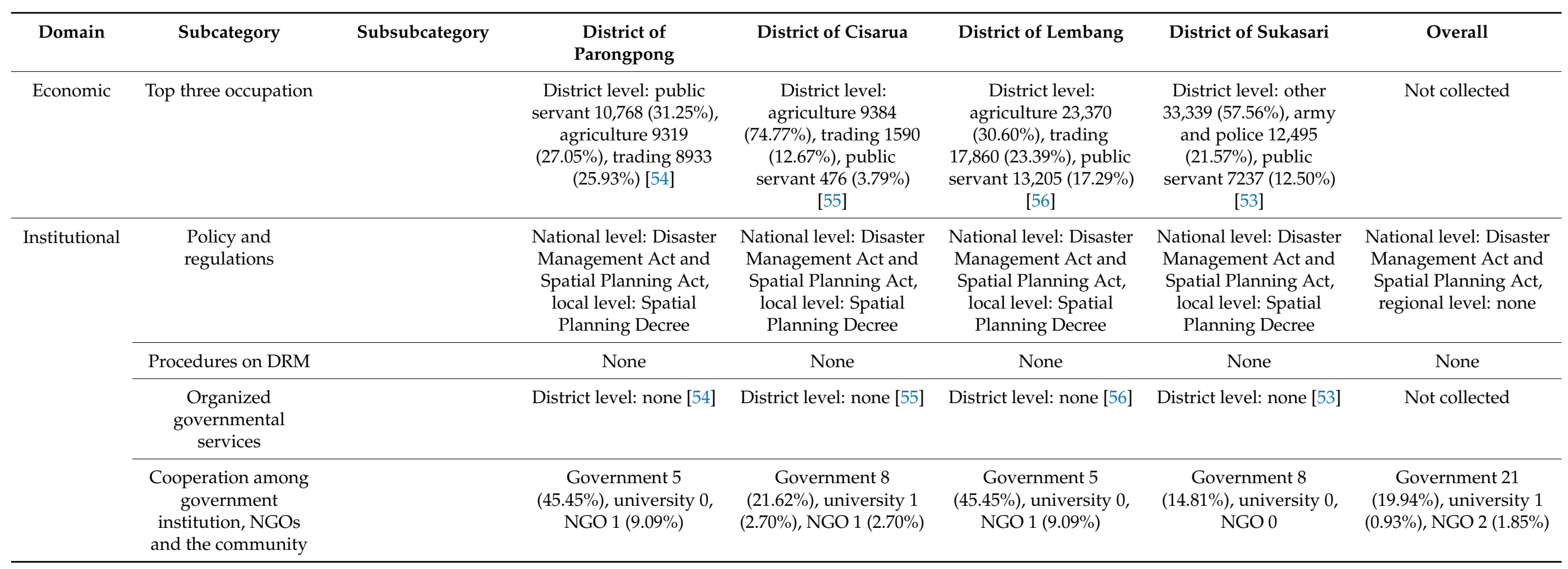


Table 1. Cont.

\begin{tabular}{|c|c|c|c|c|c|c|c|}
\hline Domain & Subcategory & Subsubcategory & $\begin{array}{c}\text { District of } \\
\text { Parongpong }\end{array}$ & District of Cisarua & District of Lembang & District of Sukasari & Overall \\
\hline \multirow[t]{6}{*}{ Infrastructural } & $\begin{array}{l}\text { Transportation } \\
\text { infrastructure }\end{array}$ & & $\begin{array}{l}\text { District level: } \\
\text { asphalt, good all } \\
\text { year long [58] }\end{array}$ & $\begin{array}{l}\text { District level: asphalt, } \\
\text { good all year long [59] }\end{array}$ & $\begin{array}{l}\text { District level: asphalt, } \\
\text { good all year long [60] }\end{array}$ & $\begin{array}{l}\text { District level: asphalt, } \\
\text { good all year long [53] }\end{array}$ & \\
\hline & $\begin{array}{c}\text { Disaster } \\
\text { management } \\
\text { infrastructure }\end{array}$ & Evacuation area/spot & $\begin{array}{c}\text { Yes } 4(36.36 \%) \text {, } \\
\text { none } 6(54.55 \%) \text {, no } \\
\text { idea } 1(9.09 \%)\end{array}$ & $\begin{array}{c}\text { Yes } 5(13.51 \%), \text { none } 28 \\
(75.68 \%), \text { no idea } 4 \\
(10.81 \%)\end{array}$ & $\begin{array}{l}\text { Yes } 29(53.70 \%) \text {, none } \\
25(46.30 \%) \text {, no idea } 0\end{array}$ & $\begin{array}{c}\text { Yes } 5(83.33 \%), \text { none } 0 \\
\text { no idea } 1(16.67 \%)\end{array}$ & $\begin{array}{c}\text { Yes } 43(39.81 \%) \text {, none } \\
59(54.63 \%) \text {, no idea } 6 \\
(5.56 \%)\end{array}$ \\
\hline & & $\begin{array}{c}\text { Type of evacuation } \\
\text { area/spot }\end{array}$ & $\begin{array}{c}\text { Emergency outdoor } \\
\text { meeting spot } 2 \\
(50.00 \%), \text { public } \\
\text { facility } 1(25.00 \%), \\
\text { not defined } 1 \\
(25.00 \%), \text { faraway } 0\end{array}$ & $\begin{array}{c}\text { Emergency outdoor } \\
\text { meeting spot } 1 \\
(20.00 \%), \text { public facility } \\
0, \text { not defined } 4 \\
(80.00 \%) \text {, faraway } 0\end{array}$ & $\begin{array}{l}\text { Emergency outdoor } \\
\text { meeting spot } 20(68.97), \\
\text { public facility } 1(3.45 \%), \\
\text { not defined } 7(24.12 \%), \\
\text { faraway } 1(3.45 \%)\end{array}$ & $\begin{array}{l}\text { Emergency outdoor } \\
\text { meeting spot } 5(100 \%), \\
\text { public facility } 0, \text { not } \\
\text { defined } 0 \text {, faraway } 0\end{array}$ & $\begin{array}{c}\text { Emergency outdoor } \\
\text { meeting spot } 28 \\
(65.12 \%), \text { public facility } \\
2(4.65 \%) \text {, not defined } \\
12(27.91 \%), \text { faraway } 1 \\
(2.33 \%)\end{array}$ \\
\hline & & $\begin{array}{c}\text { Access to evacuation } \\
\text { area }\end{array}$ & $\begin{array}{c}\text { Good } 4(36.36 \%), \\
\text { bad } 0 \text {, faraway } 0, \\
\text { none } 0, \text { no idea } 7 \\
(63.64 \%)\end{array}$ & $\begin{array}{c}\text { Good } 6(16.22 \%), \text { bad } 1 \\
(2.70 \%), \text { faraway } 0 \\
\text { none } 17(45.95 \%), \text { no } \\
\text { idea } 13(35.14 \%)\end{array}$ & $\begin{array}{c}\text { Good } 32(59.26 \%), \text { bad } \\
1(1.85 \%), \text { faraway } 4 \\
(7.41 \%), \text { none } 4(7.41 \%), \\
\text { no idea } 13(24.07 \%)\end{array}$ & $\begin{array}{c}\text { Good } 5(83.33 \%), \text { bad } 0, \\
\text { faraway } 0, \text { none } 0, \text { no } \\
\text { idea } 1(16.67 \%)\end{array}$ & $\begin{array}{c}\text { Good } 47(43.52 \%) \text {, bad } \\
2(1.85 \%), \text { faraway } 4 \\
(3.70 \%), \text { none } 21 \\
(19.44 \%), \text { no idea } 34 \\
(31.48 \%)\end{array}$ \\
\hline & Land use/land cover & & Not collected & Not collected & Not collected & Not collected & See Table 3 \\
\hline & Structural design & $\begin{array}{l}\text { Need for structural } \\
\text { reinforcement }\end{array}$ & $2(18.18 \%)$ & $10(27.03 \%)$ & $8(14.81 \%)$ & $3(50.00 \%)$ & $23(21.30 \%)$ \\
\hline
\end{tabular}


Table 1. Cont.

\begin{tabular}{|c|c|c|c|c|c|c|c|}
\hline Domain & Subcategory & Subsubcategory & $\begin{array}{c}\text { District of } \\
\text { Parongpong }\end{array}$ & District of Cisarua & District of Lembang & District of Sukasari & Overall \\
\hline \multirow[t]{5}{*}{ Environmental } & $\begin{array}{l}\text { Natural } \\
\text { environment } \\
\text { condition }\end{array}$ & $\begin{array}{c}\text { Forest cover and } \\
\text { water body change }\end{array}$ & Not collected & Not collected & Not collected & Not collected & See Table 3 \\
\hline & $\begin{array}{c}\text { Built } \\
\text { environment } \\
\text { condition }\end{array}$ & $\begin{array}{l}\text { Settlement and } \\
\text { agricultural cover } \\
\text { change }\end{array}$ & Not collected & Not collected & Not collected & Not collected & See Table 3 \\
\hline & Types of disaster & $\begin{array}{c}\text { Scientific or } \\
\text { community report }\end{array}$ & $\begin{array}{c}\text { Earthquake [32], } \\
\text { volcanic eruption [47] }\end{array}$ & $\begin{array}{c}\text { Earthquake [32], } \\
\text { volcanic eruption [47] }\end{array}$ & $\begin{array}{c}\text { Earthquake [32], flood } \\
\text { [46], volcanic } \\
\text { eruption [47] }\end{array}$ & $\begin{array}{c}\text { Earthquake [32], } \\
\text { volcanic eruption [47] }\end{array}$ & $\begin{array}{c}\text { Earthquake [32], flood } \\
\text { [46], volcanic } \\
\text { eruption [47] }\end{array}$ \\
\hline & & People's knowledge ${ }^{2}$ & $\begin{array}{c}\text { Earthquake } 8(72.73 \%), \\
\text { landslide } 0, \text { volcanic } \\
\text { eruption } 1(9.09 \%), \\
\text { flood } 0, \text { not specified } 2 \\
(18.18 \%), \text { no idea } 0, \\
\text { none } 0\end{array}$ & $\begin{array}{c}\text { Earthquake } 23 \\
(62.16 \%), \text { landslide } 2 \\
(5.41 \%), \text { volcanic } \\
\text { eruption } 2(5.41 \%), \\
\text { flood } 0, \text { not specified } 1 \\
(2.70 \%), \text { no idea } 4 \\
(10.81 \%), \text { none } 5 \\
(13.51 \%)\end{array}$ & $\begin{array}{c}\text { Earthquake } 27 \\
(50.00 \%), \text { landslide } 4 \\
(7.41 \%), \text { volcanic } \\
\text { eruption } 0, \text { flood } 1 \\
(1.85 \%), \text { not specified } \\
11(20.37 \%), \text { no idea } 6 \\
(11.11 \%), \text { none } 6 \\
(11.11 \%)\end{array}$ & $\begin{array}{c}\text { Earthquake } 6(100 \%), \\
\text { landslide } 0, \text { volcanic } \\
\text { eruption } 1(16.67 \%), \\
\text { flood } 0, \text { not specified } 0, \\
\text { no idea } 0, \text { none } 0\end{array}$ & $\begin{array}{c}\text { Earthquake } 64 \\
(59.26 \%), \text { landslide } 6 \\
(5.56 \%), \text { volcanic } \\
\text { eruption } 4(3.70 \%), \\
\text { flood } 1(0.93 \%), \text { not } \\
\text { specified } 14(12.96 \%) \text {, } \\
\text { no idea } 10(9.26 \%) \text {, } \\
\text { none } 11(10.19 \%)\end{array}$ \\
\hline & Levels of hazard & & $\begin{array}{c}\text { Earthquake high [32], } \\
\text { volcanic eruption } \\
\text { high [47] }\end{array}$ & $\begin{array}{c}\text { Earthquake high [32], } \\
\text { volcanic eruption } \\
\text { high [47] }\end{array}$ & $\begin{array}{c}\text { Earthquake high [32], } \\
\text { flood high [46], } \\
\text { volcanic eruption } \\
\text { high [47] }\end{array}$ & $\begin{array}{c}\text { Earthquake high [32], } \\
\text { volcanic eruption } \\
\text { high [47] }\end{array}$ & $\begin{array}{c}\text { Earthquake high [32], } \\
\text { flood high [46], } \\
\text { volcanic eruption } \\
\text { high [60] }\end{array}$ \\
\hline
\end{tabular}


Table 1. Cont.

\begin{tabular}{|c|c|c|c|c|c|c|c|}
\hline Domain & Subcategory & Subsubcategory & $\begin{array}{l}\text { District of } \\
\text { Parongpong }\end{array}$ & District of Cisarua & District of Lembang & District of Sukasari & Overall \\
\hline \multirow[t]{4}{*}{$\begin{array}{c}\text { Land } \\
\text { administration }\end{array}$} & $\begin{array}{l}\text { Social function of } \\
\text { land }\end{array}$ & & $\begin{array}{c}\text { Over } 10 \text { years } 10 \\
(90.91 \%) \text {, between } 5 \\
\text { and } 10 \text { years } 0 \text {, below } 5 \\
\text { years } 1(9.09 \%)\end{array}$ & $\begin{array}{c}\text { Over } 10 \text { years } 25 \\
(67.57 \%), \text { between } 5 \\
\text { and } 10 \text { years } 8(21.62 \%), \\
\text { below } 5 \text { years } 4 \\
(10.81 \%)\end{array}$ & $\begin{array}{c}\text { Over } 10 \text { years } 47 \\
(87.04 \%) \text {, between } 5 \\
\text { and } 10 \text { years } 5(9.26 \%), \\
\text { below } 5 \text { years } 2(3.70 \%)\end{array}$ & $\begin{array}{c}\text { Over } 10 \text { years } 5 \\
(83.33 \% \%) \text {, between } 5 \\
\text { and } 10 \text { years } 1(16.67 \%) \text {, } \\
\text { below } 5 \text { years } 0\end{array}$ & $\begin{array}{c}\text { Over } 10 \text { years } 87 \\
(80.56 \%) \text {, between } 5 \\
\text { and } 10 \text { years } 14(12.96), \\
\text { below } 5 \text { years } 7(6.48 \%)\end{array}$ \\
\hline & $\begin{array}{c}\text { Economic function } \\
\text { of land }\end{array}$ & & $\begin{array}{c}\text { Below } 5 \mathrm{~km} 6(54.55 \%), \\
\text { between } 5 \text { and } 10 \mathrm{~km} 1 \\
(9.09 \%), \text { Over } 10 \mathrm{~km} 1 \\
(9.09 \%), \text { vary } 3 \\
(27.27 \%)\end{array}$ & $\begin{array}{c}\text { Below } 5 \mathrm{~km} 29 \\
(78.38 \%), \text { between } 5 \\
\text { and } 10 \mathrm{~km} 3(8.11 \%) \text {, } \\
\text { Over } 10 \mathrm{~km} 5(13.51 \%), \\
\text { vary } 0\end{array}$ & $\begin{array}{c}\text { Below } 5 \mathrm{~km} 33 \\
(61.11 \%), \text { between } 5 \\
\text { and } 10 \mathrm{~km} 7(12.96 \%), \\
\text { Over } 10 \mathrm{~km} 8(14.81 \%), \\
\text { vary } 6(11.11 \%)\end{array}$ & $\begin{array}{c}\text { Below } 5 \mathrm{~km} 1(16.67 \%), \\
\text { between } 5 \text { and } 10 \mathrm{~km} 2 \\
(33.33 \%), \text { Over } 10 \mathrm{~km} 0, \\
\text { vary } 3(50.00 \%)\end{array}$ & $\begin{array}{c}\text { Below } 5 \mathrm{~km} 69 \\
(63.89 \%), \text { between } 5 \\
\text { and } 10 \mathrm{~km} 13(12.04 \%), \\
\text { Over } 10 \mathrm{~km} 14 \\
(12.96 \%), \text { vary } 12 \\
(11.11 \%)\end{array}$ \\
\hline & $\begin{array}{l}\text { Physical function of } \\
\text { land }\end{array}$ & & Not collected & Not collected & Not collected & Not collected & See Table 3 \\
\hline & $\begin{array}{l}\text { Policy, regulations } \\
\text { and activities on } \\
\text { land administration } \\
\text { for DRM }\end{array}$ & & $\begin{array}{l}\text { National level: Basic } \\
\text { Agrarian Act and } \\
\text { Spatial Planning Act, } \\
\text { local level: Spatial } \\
\text { Planning Decree }\end{array}$ & $\begin{array}{l}\text { National level: Basic } \\
\text { Agrarian Act and } \\
\text { Spatial Planning Act, } \\
\text { local level: Spatial } \\
\text { Planning Decree }\end{array}$ & $\begin{array}{l}\text { National level: Basic } \\
\text { Agrarian Act and } \\
\text { Spatial Planning Act, } \\
\text { local level: Spatial } \\
\text { Planning Decree }\end{array}$ & $\begin{array}{l}\text { National level: Basic } \\
\text { Agrarian Act and } \\
\text { Spatial Planning Act, } \\
\text { local level: Spatial } \\
\text { Planning Decree }\end{array}$ & $\begin{array}{l}\text { National level: Basic } \\
\text { Agrarian Act and } \\
\text { Spatial Planning Act, } \\
\text { regional level: none }\end{array}$ \\
\hline
\end{tabular}

${ }^{1}$ All data were acquired from structured interviews, unless otherwise stated. ${ }^{2}$ Several respondents provided more than one answers for this question. 


\section{References}

1. Patel, S.; Rogers, M.B.; Amlôt, R.; Rubin, G.J. What Do We Mean by 'Community Resilience'? A Systematic Literature Review of How It Is Defined in the Literature. PLoS Curr. 2017, 9. [CrossRef]

2. $\quad$ Lemyre, L.; Clément, M.; Corneil, W.; Craig, L.; Boutette, P.; Tyshenko, M.; Karyakina, N.; Clarke, R.; Krewski, D. A Psychosocial Risk Assessment and Management Framework to Enhance Response to CBRN Terrorism Threats and Attacks. Biosecurity Bioterror. Biodefense Strat. Pract. Sci. 2005, 3, 316-330. [CrossRef] [PubMed]

3. Paton, D.; Millar, M.; Johnston, D. Community Resilience to Volcanic Hazard Consequences. Nat. Hazards 2001, 24, 157-169. [CrossRef]

4. Norris, F.H.; Stevens, S.P.; Pfefferbaum, B.; Wyche, K.F.; Pfefferbaum, R.L. Community Resilience as a Metaphor, Theory, Set of Capacities, and Strategy for Disaster Readiness. Am. J. Community Psychol. 2007, 41, 127-150. [CrossRef] [PubMed]

5. Cox, R.S.; Perry, K.-M.E. Like a Fish Out of Water: Reconsidering Disaster Recovery and the Role of Place and Social Capital in Community Disaster Resilience. Am. J. Community Psychol. 2011, 48, 395-411. [CrossRef] [PubMed]

6. Bonanno, G.A. Loss, Trauma, and Human Resilience: Have We Underestimated the Human Capacity to Thrive After Extremely Aversive Events? Am. Psychol. 2004, 59, 20-28. [CrossRef]

7. Gibson, C.A. An integrated approach to managing disruption-related risk: Life and death in a model community. J. Bus. Contin. Emerg. Plan. 2010, 4, 246-261.

8. UK Cabinet Office. Draft Strategic National Framework on Community Resilience; UK Cabinet Office: London, UK, 2010.

9. Ahmed, R.; Seedat, M.; van Niekerk, A.; Bulbulia, S. Discerning Community Resilience in Disadvantaged Communities in the Context of Violence and Injury Prevention. S. Afr. J. Psychol. 2004, 34, 386-408. [CrossRef]

10. Committee on Increasing National Resilience to Hazards and Disasters, Committee on Science E, and Public Policy. Disaster Resilience: A National Imperative; National Academy of Science: Washington, DC, USA, 2012.

11. UNISDR. 2009 UNISDR Terminology on Disaster Risk Reduction. Available online: https://www.preventionweb.net/files/7817 _UNISDRTerminologyEnglish.pdf (accessed on 1 September 2021).

12. Keim, M.E. Building Human Resilience: The Role of Public Health Preparedness and Response as an Adaptation to Climate Change. Am. J. Prev. Med. 2008, 35, 508-516. [CrossRef]

13. Pfefferbaum, R.L.; Pfefferbaum, B.; Van Horn, R.L.; Klomp, R.W.; Norris, F.H.; Reissman, D.B. The Communities Advancing Resilience Toolkit (CART): An Intervention to Build Community Resilience to Disasters. J. Public Health Manag. Pract. 2013, 19, 250-258. [CrossRef]

14. Cutter, S.; Ahearn, J.A.; Amadei, B.; Crawford, P.; Eide, E.A.; Galloway, G.E.; Goodchild, M.F.; Kunreuther, H.C.; Li-Vollmer, M.; Schoch-Spana, M.; et al. Disaster Resilience: A National Imperative. Environment 2013, 55, 25-29. [CrossRef]

15. BNPB. Bencana Tahun 2010. 2010. Available online: https://bnpb.go.id/infografis/kejadian-bencana-tahun-2010 (accessed on 1 September 2021).

16. BNPB. Bencana Tahun 2011. 2011. Available online: https://bnpb.go.id/infografis/kejadian-bencana-tahun-2011 (accessed on 1 September 2021).

17. BNPB. Bencana Tahun 2012. 2012. Available online: https://bnpb.go.id/infografis/kejadian-bencana-tahun-2012 (accessed on 1 September 2021).

18. BNPB. Bencana Tahun 2013. 2013. Available online: https://bnpb.go.id/infografis/kejadian-bencana-tahun-2013 (accessed on 1 September 2021).

19. BNPB. Bencana Tahun 2014. 2014. Available online: https://bnpb.go.id/infografis/kejadian-bencana-tahun-2014 (accessed on 1 September 2021).

20. BNPB. Bencana Tahun 2015. 2015. Available online: https://bnpb.go.id/infografis/kejadian-bencana-tahun-2015 (accessed on 1 September 2021).

21. BNPB. Bencana Tahun 2016. 2016. Available online: https://bnpb.go.id/infografis/kejadian-bencana-tahun-2016 (accessed on 1 September 2021).

22. BNPB. Bencana Tahun 2017. 2017. Available online: https://bnpb.go.id/infografis/kejadian-bencana-tahun-2017 (accessed on 1 September 2021).

23. BNPB. Bencana Tahun 2018. 2018. Available online: https://bnpb.go.id/infografis/kejadian-bencana-tahun-2018 (accessed on 1 September 2021).

24. BNPB. Bencana Tahun 2019. 2019. Available online: https://bnpb.go.id/infografis/kejadian-bencana-tahun-2019 (accessed on 1 September 2021).

25. BNPB. Bencana Tahun 2020. 2020. Available online: https://bnpb.go.id/infografis/kejadian-bencana-tahun-2020 (accessed on 1 September 2021).

26. Viverita, V.; Kusumastuti, R.D.; Husodo, Z.A.; Suardi, L.; Danarsari, D.N. Households Perceptions on Factors Affecting Resilience towards Natural Disasters in Indonesia. South East Asian J. Manag. 2014, 8, 13-28. [CrossRef]

27. Wijagsono, O.; Muryani, C.; Prihadi, S. Community resilience and adaptation strategy of flood disasters in trucuk district, bojonegoro regency. GeoEco J. 2019, 5, 181-191. [CrossRef]

28. Shalih, O.; Setiadi, H.; Nurlambang, T.; Sumadio, W. Toward a Community Resilience Framework for Disaster Risk Management: A Case Study Landslide Cisolok in Sukabumi 2018 and Sunda Strait Tsunami in Pandeglang 2018. In E3S Web of Conferences 2020 , Proceeding of the 4th ICEEDM, Padang, Indonesia, 26-27 September 2019; University of Andalas: Padang, Indonesia, 2019. 
29. Abdulharis, R. Land Administration in Post-Disaster Areas: Case Study of Banda Aceh, Indonesia. Master's Thesis, Delft University of Technology, Delft, The Netherlands, 2 October 2006.

30. Handayani, A.P.; Abdulharis, R.; Pamumpuni, A.; Meilano, I.; Hendriatiningsih, S.; Hernandi, A.; Leksono, B.E.; Saptari, A.Y.; Widyastuti, R. Assessment of Perception on Disaster Proneness of Lembang Fault in District of Cisarua, West Java Indonesia. IOP Conf. Ser. Earth Environ. Sci. 2021, 936, 012014. [CrossRef]

31. Meilano, I.; Abidin, H.Z.; Andreas, H.; Gumilar, I.; Sarsito, D.; Hanifa, R.; Rino; Harjono, H.; Kato, T.; Kimata, F.; et al. Slip Rate Estimation of the Lembang Fault West Java from Geodetic Observation. J. Disaster Res. 2012, 7, 12-18. [CrossRef]

32. Daryono, M.R.; Natawidjaja, D.H.; Sapiie, B.; Cummins, P. Tectonophysics Earthquake Geology of the Lembang Fault, West Java, Indonesia. Tectonophysics 2018, 751, 180-191. [CrossRef]

33. BPBD Jawa Barat. Dokumen Rencana Kontijensi: Bencana Gempa Bumi Akibat Sesar Lembang; BPBD Jawa Barat: Bandung, Indonesia, 2019.

34. Teo, M.; Goonetilleke, A.; Ziyath, A. An Integrated Framework for Assessing Community Resilience in Disaster Management. In Proceedings of the 9th Annual International Conference of the International Institute for Infrastructure Renewal and Reconstruction, Brisbane, Australia, 8-10 July 2013; Barnes, G., Ed.; Queensland University of Technology: Brisbane, Australia, 2015; pp. 309-314.

35. Ostadtaghizadeh, A.; Ardalan, A.; Paton, D.; Jabbari, H.; Khankeh, H.R. Community Disaster Resilience: A Systematic Review on Assessment Models and Tools. PLoS Curr. 2015, 7. [CrossRef] [PubMed]

36. Becker, J.; Paton, D.; Johnston, D.; Ronan, K.; McClure, J. The role of prior experience in informing and motivating earthquake preparedness. Int. J. Disaster Risk Reduct. 2017, 22, 179-193. [CrossRef]

37. Bronfman, N.C.; Cisternas, P.C.; Repetto, P.B.; Castañeda, J.V. Natural disaster preparedness in a multi-hazard environment: Characterizing the sociodemographic profile of those better (worse) prepared. PLoS ONE 2019, 14, e0214249. [CrossRef]

38. Sarker, M.N.I.; Peng, Y.; Yiran, C.; Shouse, R.C. Disaster resilience through big data: Way to environmental sustainability. Int. J. Disaster Risk Reduct. 2020, 51, 101769. [CrossRef]

39. Gizzi, F.T.; Kam, J.; Porrini, D. Time windows of opportunities to fight earthquake under-insurance: Evidence from Google Trends. Humanit. Soc. Sci. Commun. 2020, 7, 61. [CrossRef]

40. Williamson, I.; Enemark, S.; Wallace, J.; Rajabifard, A. Land Administration for Sustainable Development; ESRI Press Academic: Redlands, CA, USA, 2010; ISBN 9781589480414.

41. Dale, P.; McLaughlin, J. Land Administration; Oxford University Press: New York, NY, USA, 1999; ISBN 978-0-19823-390-9.

42. Unger, E.; Bennet, R.; Lemmen, C.; Dijkstra, P. Bridging the Gap of Land Administration and Disaster Risk Management: A Key Step in Climate Change Response. In Proceedings of the FIG Working Week 2020 Smart Surveyors for Land and Water Management, Amsterdam, The Netherlands, 10-14 May 2020; p. 10702.

43. Widiantono, D.J.; Supriatna, A.; Nugroho, W.A.; Abdulharis, R. Konsolidasi Tanah dalam rangka Penataan Kawasan Pasca Bencana Gempa Bumi di Kabupaten Lombok Utara, Provinsi Nusa Tenggara Barat. Buletin. Penataan Ruang 2019, 1, 23-30.

44. Handayani, A.P. Sukses Konsolidasi Tanah Pasca Bencana. Media Indonesia 2021, 10, 16.

45. Tjokropandojo, D.S.; Aqmarini, A.; Fiisabiilillah, D.F. Modal sosial dalam menumbuhkan dan mendifusikan inovasi pertanian hortikultura sebagai basis pengembangan ekonomi lokal studi kasus: Kabupaten bandung dan bandung barat. Tata Loka 2019, 21, 115-128. [CrossRef]

46. Joestiana, A.; Head of Volunteer for Disaster Management in Lembang, East Java, Indonesia. Personal communication, 2021.

47. Fitriani, I.D.; Zulkarnaen, W.; Bagianto, A. Natural Disaster Mitigation Management in the case of Mount Tangkuban Parahu Eruption in West Java. J. Phys. Conf. Ser. 2021, 1764, 012054. [CrossRef]

48. Ministry of Land, Infrastructure, Transport and Tourism. Outline of the Sediment Hazard Prevention Act. Japan. nd. Available online: https:/ / www.mlit.go.jp/river/sabo/dosyahou_review/01/110803_shiryo2.pdf (accessed on 6 November 2021).

49. Ministry of Land, Infrastructure, Transport and Tourism. Status of Designation of Sediment Disaster Prevention Areas as of the End of March 2021. Available online: https:/ /www.mlit.go.jp/common/001406980.pdf (accessed on 6 November 2021).

50. Isouchi, C.; Tsuda, Y.; Nonomura, A. Proposal for utilization of community disaster management plan system in flood high risk area-in the case on evacuation behavior of disabled person AT heavy rain disaster. J. Jpn. Soc. Civ. Eng. Ser. F6 2019, 75, I_75-I_82. [CrossRef]

51. Kagehara; Takahama District, City of Ehime Prefecture, Japan. Personal communication, 2019.

52. Fire and Disaster Management Agency. White Paper on Fire and Disaster Management; Ministry of Internal Affairs and Communications: Tokyo, Japan, 2018.

53. BPS Kota Bandung. Kecamatan Sukasari Dalam Angka 2020; BPS Kota Bandung: Bandung, Indonesia, 2020.

54. BPS Kabupaten Bandung Barat. Kecamatan Parongpong Dalam Angka 2017; BPS Kabupaten Bandung Barat: Padalarang, Indonesia, 2017.

55. BPS Kabupaten Bandung Barat. Kecamatan Cisarua Dalam Angka 2017; BPS Kabupaten Bandung Barat: Padalarang, Indonesia, 2017.

56. BPS Kabupaten Bandung Barat. Kecamatan Lembang Dalam Angka 2017; BPS Kabupaten Bandung Barat: Padalarang, Indonesia, 2017.

57. BPS Kota Bandung. Kecamatan Sukasari Dalam Angka 2017; BPS Kota Bandung: Bandung, Indonesia, 2017.

58. BPS Kabupaten Bandung Barat. Kecamatan Parongpong Dalam Angka 2020; BPS Kabupaten Bandung Barat: Padalarang, Indonesia, 2020.

59. BPS Kabupaten Bandung Barat. Kecamatan Cisarua Dalam Angka 2020; BPS Kabupaten Bandung Barat: Padalarang, Indonesia, 2020.

60. BPS Kabupaten Bandung Barat. Kecamatan Lembang Dalam Angka 2020; BPS Kabupaten Bandung Barat: Padalarang, Indonesia, 2020. 